\title{
Representing Kingship and Imagining Empire in Southern Dynasties Court Poetry
}

\section{Citation}

Tian, Xiaofei. 2016. Representing Kingship and Imagining Empire in Southern Dynasties Court Poetry. T'oung Pao 102 (1-3): 18-73.

\section{Published Version}

doi:10.1163/15685322-10213P03

\section{Permanent link}

http://nrs.harvard.edu/urn-3:HUL.InstRepos:29037384

\section{Terms of Use}

This article was downloaded from Harvard University's DASH repository, and is made available under the terms and conditions applicable to Open Access Policy Articles, as set forth at http:// nrs.harvard.edu/urn-3:HUL.InstRepos:dash.current.terms-of-use\#OAP

\section{Share Your Story}

The Harvard community has made this article openly available.

Please share how this access benefits you. Submit a story.

Accessibility 
Representing Kingship and Imagining Empire in Southern Dynasties Court Poetry ${ }^{*}$

\section{Xiaofei Tian}

(Harvard University)

Abstract: Before the fifth century, the imperial identity of a ruler seems to have disabled him as a writer rather than encouraged him to be more prolific. Literary production gradually became centered in the court by mid-fifth century, and a distinct feature of the Southern Dynasties literature is the phenomenon that emperors and princes joined with their courtiers in the act of writing poetry on social occasions. This paper focuses on a number of poems by Yan Yanzhi (384-456), Liu Yilong (407-453), Xie Tiao (464-499), Shen Yue (441-513) and Liu Xiaochuo (481-539) that represent kingship and empire and thereby become a means of disseminating and implementing imperial power. In particular, it examines the physical and discursive construction of the capital Jiankang. This paper argues that the Southern Dynasties court poetry was instrumental in the performance of sovereignty and the envisioning of the new, southern empire.

Keywords: Southern Dynasties court poetry; representation of kingship and empire; Yan Yanzhi; Liu Yilong (Emperor Wen of the Song); Xie Tiao; Shen Yue; Liu Xiaochuo

In the year 446, Emperor Wen of the Song 宋文帝 (r. 424-453) had an artificial hill, known as Jingyang Hill 景陽山, constructed in one of the imperial parks of the capital city of

\footnotetext{
* I wish to thank the readers of this article for their feedback. Any remaining fault is clearly my own.
} 
Jiankang; on top of the hill, a tower known as the Jingyang Tower was erected. ${ }^{1}$ During one of the emperor's visits to the tower, he composed a poem, "On Ascending the Jingyang Tower" (“Deng Jingyang lou” 登景陽樓), of which eight couplets have survived. ${ }^{2}$ Two other poems on the same topic are partially extant, one by the famous court poet Yan Yanzhi 顏延之 (384-456) in two couplets, and the other by the emperor's younger brother Liu Yigong 劉義恭 (413-465), the Prince of Jiangxia 江夏, in eight couplets. ${ }^{3}$ Although we cannot know for sure if these poems were all composed on the same occasion, the striking similarity between the emperor's and the prince's poems, whose extant versions are both long enough for a meaningful comparison, indicates that the prince wrote his poem as a companion piece to the emperor's. Despite their fragmentary nature, this is a notable set of poems, because this is the earliest explicit textual evidence that we have of an emperor and an imperial prince being engaged in social composition of poetry together and along with their courtier(s).

Before we ask the question, "What is happening?" we might want to step back and examine this assertion, which, to anyone even vaguely familiar with the classical Chinese poetic tradition, might come across as startling, because it is well known that, in the words of Jack W. Chen, "Throughout the long history of traditional China, many emperors, if not most, composed

\footnotetext{
${ }^{1}$ Song shu (Beijing: Zhonghua shuju, 1974), 5.94.

${ }^{2}$ Lu Qinli ， comp. Xian Qin Han Wei Jin nanbeichao shi ～(Beijing: Zhonghua shuju, 1995),

1137. The source of the longer fragment is the early seventh-century encyclopedia Yiwen leiju (Taipei:

Wenguang chubanshe, 1974), 63.1131. The shorter fragment is from the tenth-century encyclopedia Taiping yulan (rpt. Taibei: Shangwu yinshuguan, 1975), 358.1777.

${ }^{3}$ Lu Qinli, 1237, 1248; Yiwen leiju 28.501-502.
} 
some poetry." "However, we need a precise understanding of the imperial poetic composition and the discursive conventions surrounding it if we are to appreciate the larger cultural and political changes implied in the phenomenon of the fifth century.

It is noteworthy that Han emperors and princes known or reputed to have versified did so by way of a spontaneous outburst under specific, emotion-inducing circumstances, that the songpoems are always embedded in a narrative, and that no courtier ever presumed to versify on the same topic. ${ }^{5}$ While the emperors of the Jin dynasty (265-420), which preceded the Song (420479), had commanded their courtiers to compose poetry on various public occasions, there is no indication that they themselves had ever tried their hand at writing on those occasions, and in any case we do not have any textual evidence in the extant record. Emperor Wu of the Jin 晉武帝 (236-290, r. 266-290), for instance, had held a banquet in the Hualin Park 華林園 (also known as the Fanglin Park 芳林園) in the spring of 268 and ordered his courtiers present to “compose

\footnotetext{
${ }^{4}$ The Poetics of Sovereignty: On Emperor Taizong of the Tang Dynasty (Cambridge, Mass.: Harvard Univ. Asia Center, 2010), 161.

${ }^{5}$ Examples abound, such as the Han founder Liu Bang's (247-195) song "Great Wind" , Emperor Wu of the Han's (156-86, r. 141-86) song "Huzi” ， or the "Young Emperor" Liu Bian’s ～(176-190, r. 189-190) song that reportedly was sung before he was forced to commit suicide. See Lu Qinli, 87, 93-94, 191. The only exception would seem to be the "linked verse of Boliang Terrace" _ , a set of seven-syllable lines supposedly composed by Emperor Wu of the Han and his courtiers on the newly completed Boliang Terrace (Yiwen leiju 56.1003-04), but the authenticity of this "poem" is highly problematic. Perhaps even more than the issue of inauthenticity, what strikes us about this "poem" is that the first emperor who decided to emulate the "linked verse of Boliang" was Emperor Xiaowu of the Song ～(r. 454-464); Lu Qinli 1224.
} 
poems in order to observe their aims” 賦詩觀志. ${ }^{6}$ Sun Sheng 孫盛 (302-373) claims that Ying Zhen's 應貞 (d. 269) poem “was the most elegant of the lot," and it is duly included in Wen xuan. ${ }^{7}$ Two stanzas, with the ambiguous ascription “Jin Wudi Hualin yuan ji shi” 晉武帝華林園 詩 in Yiwen leiju, turn out to be by Xun Xu 荀勖 (d. 289), with a fuller title cited in the eighthcentury encyclopedia, Chuxue ji 初學記. ${ }^{8}$ An examination of the “Bibliography” 經籍志 section of Sui shu 隋書, compiled in the early seventh century, shows that prior to the fifth century only a handful of emperors and even fewer princes had left any literary collection. ${ }^{9}$ Even in the case of Cao Pi, Emperor Wen of the Wei 魏文帝 (187-226, r. 220-226), a ruler famous for his ardor and aptitude for literary compositions, it is remarkable that most of his extant poems and poetic

\footnotetext{
${ }^{6}$ Gan Bao , Jin ji , cited in Li Shan's (d. 689) commentary on Wen xuan (Shanghai: Shanghai guji chubanshe, 1986), 20.952. The phrase "observing [their] aims" is from Zuo zhuan , in which Zhao Wu (d.
} $541 \mathrm{BCE}$ ) asked seven ministers to recite $s h i$ so that he could observe their aims, which also led him to make predictions about their future careers. Chunqiu Zuo zhuan zhushu , Duke Xiang 27, in Shisanjing zhushu (Taibei: Yiwen yinshuguan, 1955), 38.647. All citations from the "thirteen classics" in this paper are to this edition.

${ }^{7}$ Wen xuan 20.952.

${ }^{8}$ Yiwen leiju 39.714. The poem is cited as "Cong Wudi Hualin yuan yan shi” ; Chuxue ji (Beijing: Zhonghua shuju, 1962), 14.348.

${ }^{9}$ The only Han ruler with a literary collection was Emperor Wu of the Han, whose collection spans one single scroll. From four hundred years of Han rule, exactly two princes had left behind a collection, one from the Western Han and the other the Eastern Han; Sui shu $\quad$ (Beijing: Zhonghua shuju, 1973), 35.1056-57. The Cao Wei rulers-Cao Cao (155-220), Cao Pi (187-226), Cao Rui $\quad$ (206-239, r. 226-239) and Cao Mao (241-260, r. 254260)_-were exceptional in this regard, as each had had a sizable collection, even though Cao Cao was made emperor posthumously, and most of Cao Pi's extant poems and $f u$ were written before he ascended the throne. 
expositions $(f u)$, especially those composed on the same topics as his retainers, had been written long before he claimed the throne. ${ }^{10}$ Of the fifteen Jin emperors, excluding Sima Yi 司馬㰻 (179-251) and Sima Zhao 司馬昭 (211-264), who had assumed imperial titles posthumously, only three-Ming 明帝 (r. 323-325), Jianwen 簡文帝 (r. 371-372), and Xiaowu 孝武帝 (r. 372396), all Eastern Jin rulers - had left behind a collection. Remarkably, though their reigns were much shorter, Emperor Ming and Emperor Jianwen's collections were much bigger (five scrolls each) than Emperor Xiaowu's (two scrolls). ${ }^{11}$ Although we cannot prove it, an obvious conclusion is that the imperial identity seems to have disabled the ruler as a writer rather than encouraged him to be more prolific.

Thus, a distinct feature of Southern Dynasties literature is the phenomenon that emperors and princes joined with their courtiers in the act of writing on excursions and at banquets, leaving behind a great number of poems composed on such occasions. As shown above, this had by no means been common before the Liu Song period. Indeed, literary production gradually became centered in the court by the mid-fifth century. This forms a sharp contrast with the previous centuries, during which the best-known poetic collections composed by multiple authors on their outings and/or at banquets were the outcome of private gatherings: Shi Chong's

\footnotetext{
${ }^{10}$ Cao Pi's father Cao Cao was made King of Wei in 216, and Cao Pi was named the crown prince in 217. He succeeded his father to become King of Wei in early 220 and then claimed the throne later that year. Only a few poems by Cao Pi can be securely dated to a time after Cao Cao's death.

${ }^{11}$ Sui shu 35.1064. It is also worth noting that, while Emperor Ming and Jianwen's collections were still extant in the Northern Song (960-1127), Emperor Xiaowu's collection seems to have been lost. In the age of manuscript culture, this among other things shows an aggressive lack of interest in Emperor Xiaowu's collection, as the more often a collection was copied, the more opportunities it would have had for survival. Jiu Tang shu (Beijing: Zhonghua shuju, 1975), 47.2052; Xin Tang shu ～(Beijing: Zhonghua shuju, 1975), 60.1581.
} 
石崇 (249-300) Golden Valley 金谷 gathering in 296; Wang Xizhi’s 王羲之 (303-361) Lanting

蘭亭 gathering in 353; the Shimen 石門 excursion, likely led by the eminent Buddhist monk Huiyuan 慧遠 (334-416), in 400; even Tao Yuanming’s 陶淵明 (365-427) Xiechuan 斜川 gathering in $401 .^{12}$ From after the Song, however, such gatherings were largely eclipsed by salons led by emperors and princes. If in the fourth century the most famous preface to a group of poems was composed by the aristocrat Wang Xizhi in honor of a private party celebrating the Lustration Festival in provincial Kuaiji (in modern Zhejiang), then in the fifth century the two renowned pieces serving the same function were respectively written by Yan Yanzhi and Wang Rong 王融 (466-493), both celebrating the imperial banquet held on this festive day. ${ }^{13}$ While the occasion and the function remain the same, the circumstances, nature, and styles of the prose pieces are vastly different. If in the early fifth century an eminent aristocrat like Xie Lingyun 謝 靈運 (385-433) could still have his own "Four Friends," then in the late fifth century we have the “Eight Friends of the Prince of Jingling” (Jingling bayou 竟陵八友) and, in the sixth century, the

\footnotetext{
${ }^{12}$ Shi Chong's preface to the "Golden Valley Collection" has survived; see Quan Jin wen $\quad 33.1651$, in Yan
} Kejun (1762-1843), comp., Quan Shanggu Sandai Han Wei Sanguo Liuchao wen (Beijing: Zhonghua shuju, 1987; references to Yan's compilation are hereafter cited by the relevant dynasty name). Two poems (one in fragment) by the famous Western Jin poet Pan Yue $\quad(247-300)$ from this collection are extant; Lu Qinli, 632. Wang Xizhi's "Preface to the Lanting Collection" ("Lanting ji xu”_ ) is also a famous work of calligraphy; Quan Jin wen 26.1609. For “You Shimen shi xu” ee Lu Qinli, 1085-86. For Tao’s “You Xiechuan” poem and preface, see Lu Qinli, 974-75. Even in the early fifth century, we still had the Xie clan's “gathering of Black Robe [Lane]” (Song shu 58.1591).

${ }^{13}$ Yan Yanzhi's and Wang Rong's prefaces are both known as "Sanyue sanri qushui shi xu" ; see Quan Song wen $\quad 37.2630$ and Quan Qi wen $\quad$ 13.2860. Both are included as canonical pieces on this topic in Wen xuan 46. 
“Four Friends of the Eastern Palace [i.e., the Crown Prince]” (Donggong siyou 東宮四友). ${ }^{14}$ The shift is symbolic of the larger changes taking place in the cultural landscape of early medieval China. There were of course still "private" literary gatherings among elite members, but the most famous literary gatherings and much of literary and cultural production became centered in the court, and this had begun with the Song dynasty in the first half of the fifth century.

It has long been taken for granted that Southern Dynasties court poetry is light, decorative, a poetry of no "significance." There are indeed such poems in the two hundred years' rule of the southern courts, and their lightness is necessary, pointing to a certain cultural value and a certain poetic importance too often neglected by traditional moralists, historians, and even literary scholars themselves. But this article will not be concerned with those poems. Instead, it focuses on a set of court poems that represent kingship and empire and thereby become a means of disseminating and implementing imperial power, and examines the physical and discursive construction of the capital Jiankang in an act of envisioning empire.

\section{Performing Kingship: Emperor Wen's Agenda}

\footnotetext{
${ }^{14}$ The phrase "four friends" has a sense of prestige and gravity because it is traditionally used to designate Confucius' four worthy disciples and King Wen of the Zhou's four worthy ministers. Xie Lingyun "associated with his cousin Huilian, He Changyu of Donghai, Xun Yong of Yingchuan, and Yang Xuanzhi of Taishan through [their common interest in] literary writings, and they would go on outings together in the countryside. Contemporaries referred to them as [Lingyun's] 'Four Friends'”, shu 67.1774. For the Crown Prince Xiao Gang’s $\quad$ (503-551) "Four Friends of the Eastern Palace," see Nan shi (Beijing: Zhonghua shuju, 1975), 52.1304.
} 
The last two Jin emperors were completely under the control of regents and warlords. One of the warlords was the powerful general Liu Yu 劉裕 (363-422), who eventually took the throne for himself and founded the Song in 420. Liu Yu died in two years, and was succeeded by his inept teenage son Yifu 義符 (406-424, r. 422-424). His regents deposed him and had him murdered shortly thereafter; they bypassed, and eventually assassinated, Liu Yu's second son Yizhen 義真 (407-424), whom they considered too flighty to rule, and chose to put on the throne Liu Yu’s third son, Yilong 義隆 (407-453, r. 424-453), known as Emperor Wen 文帝. Emperor Wen was to be the first emperor in thirty years who ruled for an extended period of time as a mature man wielding great personal power. However, his unexpected rise demonstrates that power, the most important element of kingship, depended on the authority invested in the person of the emperor by an elite group voluntarily submitting itself to the emperor's dominance for its own profit and gain. Throughout much of his rule, Emperor Wen had to contend with this elite group, including his own brother, for power and control.

Another grave challenge facing the young emperor was an increasingly formidable opponent from the north. Liu Yu had carried out highly successful military campaigns against the northern non-Han rulers and once even recovered Chang'an 長安and Luoyang 洛陽, former capitals of the Han and Western Jin dynasties. Emperor Wen cherished the same ambition as his father had and tried several times to take back the north, but he never succeeded. In the meanwhile, the Northern Wei emperor Tuoba Tao 拓咙奉 (Emperor Taiwu 太武帝, 408-452, r. 423-452) unified north China in 439, a momentous event that ended more than a century of multiple division of north China and began the era of Northern and Southern Dynasties. It created immense political pressure on the southern dynasty, both in pragmatic terms of power balance and in terms of royal ideology and legitimacy. Thus, against a potent rival ruling over 
the Chinese heartland, and against influential elite members, Emperor Wen needed to put on a performance of kingship in such a way as to justify and legitimize the dynastic rule, and inspire a strong belief in his personal supreme authority. His experience had taught him that kingship was an unstable institution, and that power was subject to a deft manipulation of his subjects' perception of power.

Emperor Wen used considerable energy to ensure that the most powerful members of the elite never threatened his own supremacy. As soon as he felt secure on the throne, he executed those regents who had done away with his two brothers and chosen him as emperor. Although he could not have succeeded to the throne without their support, it was necessary for him to claim the legitimacy of his rule by punishing them for their regicide and assassination of a prince. As he proclaimed in an edict reinstating Yizhen as prince:

As the Kingly Way has become level and smooth, government decrees and penal institutions are now sharply defined; the bright manifestation of the body politic is hereby present.

王道既亨, 政刑始判, 宣昭國體, 於是乎在. ${ }^{15}$

Subsequently, he divided administrative responsibilities between Wang Hong 王弘 (379-432), a member of one of the most illustrious aristocratic clans in the south, and his own brother Yikang 義康 (409-451), who assumed even more prominence after Wang Hong died. But Yikang “never had had any learning, and was ignorant of propriety; he thought that brothers were the closest kin, and so no longer observed the outward traces of ruler and subject” (素無術學, 闇於大體, 自謂

${ }^{15}$ Song shu 61.1639. 
兄弟至親, 不復存君臣形迹). ${ }^{16}$ This failure to openly mark the supremacy of imperial power proved his downfall, and he was sent into exile in 440. Emperor Wen then appointed another younger brother, Yigong, as his prime minister, but Yigong learned a lesson from Yikang's disgrace, and deferred to the emperor in everything. ${ }^{17}$

The "bright manifestation of the body politic" finds physical expression in the avid construction of the cityscape of Jiankang, the heart of the southern empire, during Emperor Wen's reign. For much of the fourth century, the Eastern Jin regime had been busily engaged in quelling internal rebellions and fighting off northern threats, and the building of Jiankang was not a high priority. ${ }^{18}$ The only large-scale building project was undertaken by the prominent minister Xie An 謝安 (320-385) in 378, but for that he had had to first contend with his fellow power-holder Wang Biaozhi 王彪之 (305-377). Wang granted that the imperial palaces were "indeed modest and undersized compared to Han and Wei," but insisted that "safeguarding the state and pacifying the families" were more important tasks at hand. Xie An gave in, postponing the construction until after Wang's death. ${ }^{19}$ Wang Biaozhi and Xie An's conflict on this issue has a symbolic weight: if the former embodied a familiar Confucian discourse of frugality and conservation of human labor, then the latter represented a different kind of political vision that saw architecture as a visible symbol of the grandeur of the imperial court and of the might of the

\footnotetext{
${ }^{16}$ Ibid., 68.1790.

${ }^{17}$ Ibid., 61.1644.

${ }^{18}$ In the early fourth century, when Emperor Yuan (r. 318-323) first came to Jiankang, "both public and private resources were exhausted," so much so that even a suckling pig was considered a rare delicacy. Jin shu 晉書
}

(Beijing: Zhonghua shuju, 1974), 79.2079.

${ }^{19}$ Ibid., 76.2011-12. 
empire. Through much of the Eastern Jin, cultural legacy might have for various reasons played a larger role than palatial splendor in establishing dynastic legitimacy; ${ }^{20}$ yet, in the course of time, change took place, of which Xie An's building project was an early sign. In the second quarter of the fifth century, Emperor Wen of the Song's reign became the first peak of building and developing Jiankang in the Southern Dynasties. ${ }^{21}$ The building projects included the creation of the Northern Park 北苑, later renamed Leyou Park 樂游苑, with the erection of many towers and palaces on Upturned Boat Hill 覆舟山; ${ }^{22}$ the construction of the crown prince’s residence, a “majestic and splendid” palace, in $438 ;^{23}$ the expansion and renovation of Hualin Park 華林園

\footnotetext{
${ }^{20}$ See Cheng Yu-yu’s argument in her article "Mingshi yu ducheng: Dong Jin 'Jiankang' lunshu” : :

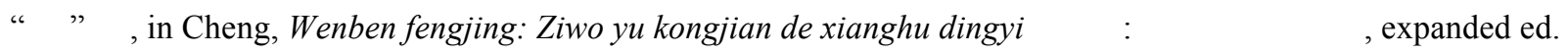
(Taibei: Maitian, 2014), 33-74.

${ }^{21}$ He Yun'ao ， Liuchao wadang yu Liuchao ducheng (Beijing: Wenwu chubanshe, 2005$), 123$. ${ }^{22}$ Jiankang shilu (Shanghai: Shanghai guji chubanshe, 1987), 12.327. Leyou Park was to the south of the Upturned Boat Hill (modern Jiuhua Hill to the northeast of Nanjing), on the site of the Eastern Jin's Northern Altar . Jiankang shilu cites Gu Yewang's _ (519-581) Yudi zhi , stating that in the midst of the Yuanjia era (Emperor Wen's reign from 424 to 453), Emperor Wen moved the Northern Altar away and built the Northern Park there. Since the emperor held a banquet at this location on the Lustration Festival in the eleventh year of the Yuanjia reign (434), the park must have been completed before that.

${ }^{23}$ Song shu 99.2423. The completion of the Eastern Palace was placed in the fifteenth year of the Yuanjia era (438). See Jiankang shilu 12.322 . 
and the construction of the Xuanwu Lake 玄武湖 in $446{ }^{24}$ and the creation of new gates for the imperial palace city in 443 and for the city of Jiankang in $448 .^{25}$

This era also witnessed the first extensive textual building of Jiankang under the aegis of Emperor Wen, which was just as important as the physical construction of the capital city to his performance of kingship. Emperor Wen both personally composed writings on important public occasions and commissioned his courtiers to do so, with Yan Yanzhi as his chief court writer. In the early winter of 433, the emperor went to the North Lake 北湖 to watch a harvest, and Yan Yanzhi was commissioned to compose the following poem on the occasion: "Written to Imperial Command on Watching the Harvest at the Fields by the Northern Lake" ("Yingzhao guan Beihu tianshou” 應詔觀北湖田收). ${ }^{26}$ The timing and location of the viewing were as symbolic as the act: the direction north also corresponds to the cold winter season in ancient Chinese cosmology; the site of the North Lake had been the Northern Altar where the emperor made annual sacrifices

${ }^{24}$ Song shu 5.94.

${ }^{25}$ Ibid., 5.90, 5.96. The western city-gate was named Changhe (name of the heavenly gate, and also the name of a western city-gate of the old Han and Western Jin capital Luoyang) and the northern gate, Guangmo (name of the northern wind).

${ }^{26} \mathrm{Li}$ Shan thought that the lake was part of the Leyou Park (Wen xuan 22.1049), but Leyou Park was to the south of Upturned Boat Hill while the lake was to the northwest of the hill. For Yan's poem, see Wen xuan 22.1049-51; Lu Qinli, 1230. For another English translation, see Tina Marie Harding, “Echoes of the Past: Yan Yanzhi’s $(384-$ 456) Lyric Shi ” (Ph.D. diss., Univ. of Colorado, 2007), 147-48; also see Fusheng Wu, Written at Imperial Command: Panegyric Poetry in Early Medieval China (Albany: State Univ. of New York Press, 2008), 90-91. All translations in the present article are the author's unless otherwise noted. Since several of the poems discussed in this article are included in the sixth-century anthology Wen xuan, Li Shan's commentary and, to a lesser extent, the Five Ministers' commentary on Wen xuan are the point of departure in identifying allusions; modern annotations are also consulted and cited whenever relevant. Those not credited are the discovery of the author of this article. 
to the Earth. ${ }^{27}$ The transfiguration of Jiankang's cityscape — relocating important ritual landmarks and making new ritualistic or symbolic space — as a performance of kingship and statecraft receives a perfect textual illumination in the masterful court poet Yan Yanzhi's hand.
周御窮軩跡 The Zhou king's chariot tracks extended to the farthest distance;
夏載歷山川 Xia’s transports traveled across mountains and rivers. ${ }^{28}$
蓄軫豈明禁 How could storing away the carriage be sagacious and virtuous?
4 善遊皆聖仙 Those good at touring were either sages or gods.

Yan opens the poem with two venerable precedents from high antiquity to establish a tradition of imperial itinerancy. Arguing against sedentary kingship, Yan pointedly stresses the importance of being "good at touring," which clearly implies that there are those who are "bad" at itpresumably if they travel in pursuit of personal pleasure. The next couplet explicitly states when imperial mobility is justified and the immediately following lines describe the present occasion:

帝暉膺順動 The imperial radiance moves according to propriety, ${ }^{29}$

\footnotetext{
${ }^{27}$ The North Altar was moved here from south of Upturned Boat Hill to make way for the Leyou Park, and later on was moved away again for the site to be converted into the North Lake. Song shu 14.346.

${ }^{28}$ As Li Shan notes, the Zhou king refers to King Mu, who famously toured through his empire; Xia's transports refer to the four vehicles used by the legendary Great Yu, founder of the Xia. The Classic of Documents records his words: "I ride in four kinds of transports" . . According to Kong Anguo's (fl. 2nd century BCE) commentary, the transports were boat on water, wagon on land, sleigh on muddy roads, and sedan on mountains ( , , , , Wen xuan 22.1050
} 
清蹕巡廣庫 Traveling on the cleared route to inspect vast plots of land.

樓觀眺豐穎 From the lofty tower He gazes at the dense ears of wheat;

8 金駕映松山 His golden carriage gleams amidst the pines on the hill.

飛奔互流綴 Speeding chariots follow one another in a flowing stream;

緹豰代迴環 Vermilion-clad archers on horseback make continuous rounds by turn.

If line 7 describes the imperial view of the golden grain from the tower on the hill, then line 8 switches to the onlookers' view of the emperor's gold-decorated carriage. ${ }^{30}$ This, as we will see, is a peculiar device employed by Yan Yanzhi, a "shifting viewpoint" that much resembles a shot transition in a modern-day film. Such a device brings attention to the camera's angle change - that is, the court poet's mediating role in representing not just the imperial view itself but also the imperial presence in the view of the subjects, in confirming the "impression" left by the emperor's bodily movement on the landscape. What the poet does is to give visibility to royal power.

To continue the filmmaking metaphor, the visually stunning move that highlights a speck of gold against the green pine-hill is a long shot that places the emperor, here indicated metonymically, in a striking relation to his surroundings. Though in movement, he appears almost immobile from a distance, and it is his retinue and the imperial guards that flow incessantly. The circling guards clothed in red liveries contribute to the vision of the imperial

\footnotetext{
${ }^{29}$ Li Shan, ibid., cites from The Classic of Changes: "The sage acts according to propriety, thus punishments are clearly defined and the people obey"

${ }^{30}$ The "golden carriage" refers specifically to a particular kind of imperial carriage known as jinlu , / with a gilded crossbar in the front. Ibid.
} 
procession as the sun's orbit, a clichéd metaphor given new life by the visual spectacle depicted here.

神行埒浮景 The divine journey equals the course of the sun's rays,

12 爭光溢中天 Its rivaling brilliance overflows in mid-sky.

開冬眷徂物 As winter opens, we gaze at the withering plants,

殘悴盈化先 Even declining and withering, they are fuller than in early spring. ${ }^{31}$

If anyone could make a chilly winter scene of dying plants sound so positive and upbeat, it must be Yan Yanzhi: in a remarkable twist, he contends that the wilting vegetation is fulleras indeed it is - than in early spring when nothing has sprouted yet.

陽陸團精氣 On the lands facing south the numinous energy gathers;

16 陰谷曳寒煙 And from the northern valley cold mist trails:

攢素既森藹 The amassed whiteness is copious and permeating,

積翠亦葱仟 Layers of verdure are lush and abundant.

息饗報嘉歲 Resting the farmers and feasting the gods, we offer thanks for a great harvest;

20 通急戒無年 Balancing grain storage for urgent needs, we guard against a year of dearth.

\footnotetext{
${ }^{31}$ Here I adopt Lü Yanji's (fl. early 8th century) explication of this couplet in the Five Ministers' commentary on Wen xuan. See Song ben liuchenzhu Wen xuan (Taibei: Guangwen shuju, 1964), 22.412.
} 
溫渥浹锤隸 Benevolent grace is spread even to common laborers;

和惠屬後筵 Gentle kindness extends to attendants in the rear.

Even though winter is not usually a time of lushness, Yan Yanzhi manages to paint a scene of bounty in lines 17-18 by depicting the "amassed whiteness" (of the cold mist of line 16) and the "layers of verdure" (of the pines of line 15). Nature's bounty is followed by feasting and ritual offerings that satisfy men as well as gods, and the landscape description in lines 15-18, which is relatively straightforward and easy to read, takes a dramatic turn toward verbal formality and density in lines 19-20: these lines showcase a condensed combination of a number of highly technical terms from the ritual classics, and effectively call attention to the change of key in the composition. ${ }^{32}$ In the next couplet, the emperor, concerned with providing for the common folk in a year of dearth, extends his grace to commomers and the lowest attendants in his vast retinue, among whom the poet finds himself. The poem then concludes with a note of modesty:

觀風久有作 Long have there been writings on observing customs，

\footnotetext{
${ }^{32}$ The imperial zha ritual was held at the end of the year to offer a feast to the gods and also to offer respite to the farmers; Li ji zhushu $\quad, 26.500-501 . L i j i$ also states that if a state does not have the storage of grain that is adequate for six years, it would be considered as being in a state of "crisis" ( $j i \quad$ ), and that the ministers must manage the expenses of the state by balancing out (tong ) the grain storage over the course of thirty years; $L i j i$ zhushu 12.238. Wu nian is literally a year of no harvest; Zhou li zhushu $\quad, 14.210$. See Wen xuan 22.1050.
} 
24 陳詩愧未妍 But I am ashamed of my lack of skill in presenting a poem. ${ }^{33}$

疲弱謝凌遽 Weak and weary, I beg off speed [in composition]:

取累非纆牽 My limitation cannot be blamed on the reins.

For the last couplet Li Shan cites a story in Zhanguo ce 戰國策 that tells of a good charioteer wondering why he could not go a thousand leagues with an excellent horse; he was told that the reins were too long. ${ }^{34}$ While the Zhanguo ce story certainly furnishes the earliest source of the allusion, Yan Yanzhi might also have had in mind a couplet from a poem in foursyllable lines by the Western Jin poet-statesman Zhang Hua 張華 (232-300): “The confining length of the reins / Has truly burdened the steed of a thousand leagues” 纆率之長, 實累千里. ${ }^{35}$ In any case, Yan Yanzhi is saying that his slowness is not due to the cumbersome reins but is because of his native ineptness as a writer. While other poets often close similar poems with the expression of exalted or grateful feelings or with a general confession of their own inferiority, Yan Yanzhi calls attention to the craftsmanship of the court poet with a self-reference to the poem being presented. This distinctive move would subsequently become a conventional ending for a court poem written at imperial command.

The Leyou Park poetic collection of 434 is another good example of the textual representation of imperial power. On the third day of the third month in the eleventh year of the

\footnotetext{
${ }^{33} \mathrm{Li}$ Shan again cites from $\mathrm{Li} i \mathrm{i}$ that the monarch must go on an eastern inspection tour in the second month of every year and commands the grand musician to present shi poems in order to observe local customs, ; Li ji zhushu 11.226. 
Yuanjia reign (March 28, 434), the emperor held a banquet in the newly renovated park, which in the Eastern Jin had been merely known as the "Herb Garden” (Yaopu 藥圃), both to celebrate the Lustration Festival and to bid farewell to two princes who were being sent to provincial postings. ${ }^{36}$ At the banquet Emperor Wen ordered all officials present to compose poems, and Yan Yanzhi was commissioned to write a preface for the collection. Although the poetic collection is largely lost, both Yan Yanzhi's poem, a stately piece in the solemn tetrasyllabic meter, and his preface, written in high-style parallel prose, are preserved in Wen xuan. ${ }^{37}$ The gathering and the poetic collection prefaced by Yan Yanzhi mark the beginning of numerous such gatherings and poetic compositions in Leyou Park throughout the Southern Dynasties; it also, as stated earlier in this article, marks a shift in literary production from the elite circle to the imperial court.

We do not know if Emperor Wen himself composed a poem on any of these occasions, but he certainly did on an outing to Hualin Park in 446 or shortly after. This was a poem on ascending the Jingyang Tower. It survives in two fragments:

\section{Fragment 1:}

崇堂臨萬雉 The lofty hall looks down on the city with walls of ten thousand $z h i{ }^{38}$

\footnotetext{
${ }^{36}$ Pei Ziye $\quad$ (469-530), Song lue , cited in Li Shan's commentary; Wen xuan 46.2049.

${ }^{37}$ The poem "Yingzhao yan qushui zuo shi" $\quad$ is in Wen xuan 20.960-65. For an English translation, see Harding, 159-61.

${ }^{38} \mathrm{Zhi}$ is an ancient measure, the actual length of which varied at different times but in general was thirty feet (sanzhang ) long and ten feet (yizhang ) high. A city with walls of "ten thousand zhi" refers to the capital city, and this is used in Ban Gu’s (32-92) "Western Capital Rhapsody" to describe Chang'an, the Western Han capital; see Quan Hou Han wen $\quad 24.602$.
} 
層樓跨九成 The soaring tower rises above nine layers.

瑤軒籠翠幌 Its alabaster balustrade is enwrapped in kingfisher curtains;

4 組幙瑿雲屏 Patterned hangings are hidden behind cloud-painted screens.

階上曉露潔 On the steps morning dew sparkles;

林下夕風清 In the grove an evening breeze refreshes.

謩藻嬛綠葉 Delicate green leaves of water plants lightly trail;

8 芳蘭媚紫荎 Purple stems lend charm to fragrant orchids.

極望周天險 I extend my gaze into the farthest distance to encompass the steep terrain,

留察浹神京 My attentive inspection spreads throughout the divine capital.

交渠紛綺錯 Crisscrossing ditches are numerous like an embellished pattern,

12 列植發華英 Trees and plants in rows produce lovely blossoms.

Fragment 2:

士女炫街里 Men and women shine forth in the streets,

軒冕曜都城 Carriages and official attire bring splendor to the capital.

萬軫楊金鏕 Myriad coaches flash golden reins;

16 千舳樹蘭旌 Thousands of ships all raise perfumed streamers.

The first extant fragment of the emperor's poem begins with a statement of the tower's relation to the mighty capital city and its soaring height. The second couplet describes the inside of the tower: it is as deep as it is tall; its interior is concealed behind layers of curtains and screens and marked with unfathomable depths. The third couplet moves out of the tower, 
describing a morning scene and an evening scene. Judging from Liu Yigong's and Yan Yanzhi's poems apparently written in response to the emperor's, there might have been a couplet about the seasons that is now missing from the extant version of the latter. The fourth couplet, offering a close-up of nature, is the most crafted of the poem and evokes Xie Lingyun: the verb in the third position of each line is carefully chosen; mei 媚 as a verb normally describes human feelings (to be fond of / to please), but is strikingly applied to inanimate objects of nature in Xie Lingyun's poems (to charm / to lend charm to). ${ }^{39}$ Here "purple stalks" refer to the newly sprouted stems of plants that are tinted with a purplish hue, and the couplet presents an early spring scene of regeneration, freshness, and fragility. The fifth couplet stresses the comprehensiveness of the imperial view. The view extends from the waterways and boulevards in the city to the space beyond the city, with, in the second extant fragment of the poem, wagons and boats arriving or departing. The capital is the central junction of land-and-water transportation and communication at the heart of the empire. ${ }^{40}$

The view that encompasses minute details close at hand and expands to the far and wide, obtained from the high vista of the Jingyang Tower, is measure and manifestation of imperial power. A few decades later, the Southern Qi (479-502) building code prescribed that "the princes' residences must not erect high-rise structures from which they could look down upon the imperial palace” 諸王邸不得起樓臨瞰宮掖. ${ }^{41}$ In a fascinating display of the complex relation

\footnotetext{
${ }^{39}$ For example, in Xie's famous "Passing by the Shi'ning Villa" : : "The green slender bamboos charm/lend charm to clear ripples" ; or in "Climbing the Lone Isle in the Midst of the River" : "The lone isle charms the midst of the stream” $\quad$; Lu Qinli, 1160, 1162.

${ }^{40}$ Neither the last two lines of the first fragment nor the those of the second fragment sound like a proper conclusion to the poem, so we are safe to assume that the final lines of the original poem are missing.

${ }^{41}$ Nan Qi shu $\quad$ (Beijing: Zhonghua shuju, 1972), 22.417.
} 
between social milieu and textual representation, the prince Liu Yigong's poem on ascending the Jingyang Tower illustrates a keen awareness of the necessity to uphold the supremacy of the imperial vision.

丹墀設金屏 On the crimson floor a golden screen is laid out;

瑤榭陳玉床 In the alabaster kiosk, jade seats are set up.

溫宮冬開燠 In the south-facing palace warmth spreads in winter;

4 清殿夏含霜 The pure halls feel frosty in summertime.

弱棥布遐馥 Delicate blossoms spread aroma far and wide;

輕葉振遠芳 Light leaves send off a sweet smell into the distance.

彌望少無際 My view stretches almost indefinitely,

8 肆焍周華疆 I extend my gaze as far as possible to encompass the glorious realm.

象關對馳道 Twin watchtowers face each other across the imperial thoroughfare,

飛廉矚方塘 The Feilian Bird looks upon the square pools. ${ }^{42}$

邸寺送暉曜 Residences and temples shine forth in splendor;

12 槐柳自成行 Locust trees and willows naturally form lines.

通川溢輕艫 The flowing river is crowded by agile vessels;

長街盈方箱 Long boulevards are filled with carriages driving abreast.

顧此爝火微 Looking at myself, such a feeble glow from torch fire,

16 胡顏廁天光 With what face could I be bathed in heaven's splendor?

\footnotetext{
${ }^{42}$ Feilian is a mythical bird and also the name of a tower in the imperial park in the Western Han.
} 
The prince's poem, also partially preserved, closely follows the pattern set by the emperor's poem. The first two lines present an interior scene, matching the second couplet of the imperial poem. Lines 3-4 describe seasonal changes, which may correspond to a missing couplet from the extant imperial version. Lines 5-6 echo the emperor's fourth couplet about the delicate spring vegetation, and lines 7-8 are a repetition of the emperor's fifth couplet depicting the view from the tower. This is followed by a description of the city in lines 9-12, with distinct echoes of the imperial poem in terms of imagery and phrasing (i.e., trees lining the streets and the splendor of the residents). Lines 13-14 describing boats and wagons are basically a rewriting of the emperor's lines 15-16. It appears that only the last two lines are the prince's own invention, expressing humility befitting a subject, yet upon closer inspection we realize that the fourth couplet belies a simple imitation: in describing his view from the tower, the prince uses the intriguing word, shao 少. Its meaning is ambiguous: “a little,” or “briefly.” Either way, it qualifies the limitlessness of his view, and yields supremacy of vision to the emperor.

Yan Yanzhi's poem of the same title (and probably written on the same occasion as well) only has two extant couplets, one on the seasons and the other on plants. These two couplets seem to correspond to the third through sixth lines of Liu Yigong's poem, though the plant couplet is divided between water and hill, which better complies with the plant couplet by Emperor Wen.

風觀要春景 The wind tower invites in spring sun;

月榭迎秋光 The moon pavilion welcomes autumn light.

沿波被華若 Along the waves splendid pollia spread; 
隨山茂貞芳 Following the contours of the hill, sweet evergreens flourish.

Together, these poems contribute to a discursive construction of the capital during the reign of Emperor Wen, who had also initiated an era of passionate building and urban developments. The reciprocity of physical reality and literary creativity marks the transformation of Jiankang into the true seat of imperial power rather than the temporary hub for the government of a refugee dynasty.

This, however, does not mean that the southern regime had given up the aspiration of unifying the Chinese realm. The same year, $446 \mathrm{CE}$, witnessed another striking composition by the emperor, as he addressed to his courtiers a communique and attached poem that expressed his feelings about conquering the north. Shen Yue 沈約 (441-513) includes the edict and the poem in the “Account of Braided Barbarians" (“Suolu zhuan” 索虜傳) in his Song shu. ${ }^{43}$ In the communique, the emperor deftly brings together the image of a literature lover and the role of the sovereign:

I have been engaged in reading since youth, and am quite fond of literary writings. Roaming in metaphysical principles and enjoying elegant phrasing, I was unable to put the books away. Since I became entangled in worldly affairs, my feelings are devoted to family and state. Although I feel the urgency of the fast-setting sun, ultimately I am beleaguered by regret and shame [about my lack of accomplishments]. Still, the land is not yet united, and military campaigns and

\footnotetext{
${ }^{43}$ Song shu 95.2341-42. Shen Yue also included another poem, composed in 44? defeat and loss of Huatai to the Northern Wei.
} 
famines occur in turn. I chant of such miserable ailments, which ever more occupy my thoughts. In addition, my illness from fatigue progressively increases, and my aspirations are waning with the passage of time. With all these happenings, the effort of composing my thoughts [for literary works] has been discontinued. Now the wicked and cruel are wandering about like ghouls, and the common folk are mired in mud and trapped by fire. Thereupon I look back on the north with concern, ${ }^{44}$ and never for a moment forget about extending succor and relief to the people of the north. I desire to bring together all different counsels offered me and make a clean sweep of the fleeing rebels. Overwhelmed by my passion, I have composed a short rhyme. My dear sirs: you all have deep feelings about the state, and will surely feel an intensified sense of righteousness in your hearts.

吾少覽篇籍，頗愛文義，遊玄習采，未能息卷。自纓紼世務，情兼家國，徒 存日朂，終有慚德。而區宇未一，師饉代有，永言斯瘼，彌干其慮。加疲疾 稍增，志隨時往，屬思之功，與事而廢。殘虐遊魂，齊民塗炭，乃眷北顧， 無忘弘拯。思總量謀，掃清逋逆，感慨之來，遂成短韻。卿等體國情深， 亦當義篤其懷也。

The communique, though short, is rhetorically intricate, as the emperor's fondness ( $a i$ 愛) for literature is replaced by his concern (juan 眷) for the suffering people, and the light-hearted

\footnotetext{
${ }^{44}$ The locus classicus is a line from the Shi jing poem, "August" ("Huangyi” ), Mao 241, which states that Heaven looks back on the west—-that is, the realm of Zhou—with favor. Mao shi zhushu , in Shisanjing zhushu, 16.567.
} 
youthful activities of "roaming" and "enjoying" are now replaced by the desire to destroy evil and rescue good; his focused efforts at writing ( $z h u$ si 屬思, literally continuous, hard thinking) are now turned into concentrated efforts (also $s i$ 思) to bring together the ministers' counsels; the ailment ( $m o$ 瘼) of the people in north China is subtly transferred to the imperial person and blended with the illness assailing the emperor's body, known to all courtiers to be brought about by the fatigue of being engaged in thought ( $p i j i$ 疲疾). ${ }^{45}$ The ending of the edict describes the courtiers as having deep feelings for the state, which linguistically echoes the self-depiction of "feelings devoted to family [that is, the Liu house] and state." This is, then, an exhortation of the courtiers to feel as the emperor feels and to intimately incorporate ( $t i$ 體) the suffering of the body politic, which is embodied by the emperor's suffering person.

The poem that is appended to this communique is a wonderful representation of royal ideology:

季父鑒禍先 Father Ji had foreseen the disaster before it happened;

辛生識機始 Master Xin recognized the crisis from the beginning. ${ }^{46}$

\footnotetext{
${ }^{45}$ Emperor Wen suffered from a chronic illness in the early years of his rule and was often too sick to deal with dayto-day state matters. "Whenever he focused on something in his mind, he would feel an intense pain in his chest as if it would burst open"; Song shu 68.1790.

${ }^{46}$ Father Ji refers to King Ji (Jili ) of Zhou, the youngest of Taibo's sons and King Wen's father, who personally led an expedition against the "barbarian" Rong . Master Xin is Xin You , a Zhou lord, who once saw a man with let-down hair making offerings at Yichuan (in modern He'nan), and prophesied that the place, which was in the Chinese heartland, would belong to the Rong people within a hundred years, because of the absence of proper Chinese rites shown by the man's unkempt hair; see Chunqiu Zuo zhuan zhushu 15.247, Duke Xi 22.
} 
崇替非無徵 Prosperity and decline do not lack omens;

興廢要有以 Rise and fall ultimately have their reasons.

4 自昔淪中畿 Ever since the loss of the kingly domain, ${ }^{47}$

儵焉盈百祀 Suddenly it has been over a hundred years.

不覩南雲陰 One no longer sees southern clouds rain，

8 但見胡風起 Only the Tatar wind blowing.

亂極治必形 When chaos is extreme, peace takes shape;

塗泰由積否 A smooth road follows accumulated hardships.

方欲涤遺氛 I am about to cleanse the remaining miasma,

12 矧乃穢邊鄙 Not to mention those now defiling the frontier.

眷言悼斯民 Looking back, I grieve for the common folk,

納隍良在己 The duty of “saving them from ditches" truly lies with me.

逝將振宏羅 I vow to raise the great net,

16 一麾同文軌 With a single shake unify scripts and wagon tracks. ${ }^{48}$

時乎豈再來 When the opportune time passes, it will never come round again,

河清難久俟 One cannot wait so long for the clearing of the River. ${ }^{49}$

\footnotetext{
${ }^{47}$ This refers to the fall of the Western Jin to the invasion of the northern non-Han peoples.

${ }^{48}$ The unification of scripts and the sizes of wagon wheels is a sign of a unified empire, harking back to these actions by the First Emperor of Qin.

${ }^{49}$ The Yellow River is muddy and supposedly clears up every thousand years. The locus classicus is a quotation in Zuo zhuan: "Zisi said, 'A Zhou poem states: 'If one must wait for the River to clear up,/How long does a man's life last' ( ， ）?” Chunqiu Zuo zhuan zhushu 30.520, Duke Xiang 8.
} 
駘而安局步 While nags are content with confined steps,

20 騏驥志千里 A handsome steed aspires to go a thousand leagues.

梁傅畜義心 The tutor of Liang cherished righteous intent;

伊相抱深恥 Minister Yi harbored profound shame. ${ }^{50}$

賞契將誰寄 Where should such intimate understanding be found?

24 要之二三子 It must be sought among the various gentlemen.

無令齊晉朝 Do not let the courts of Qi and Jin

取愧鄒魯士 Become embarrassed by men of Zou and Lu. ${ }^{51}$

Except for the opening and concluding couplets and for lines 21-22, the poem is remarkably free of allusions. It is stylistically straightforward and simple, evoking the "old poems" of the north that were popular in the south in the early fifth century, rather than the metaphysical verse of the Eastern Jin or the contemporary high court style practiced by Yan

\footnotetext{
${ }^{50}$ Liang's tutor is the Han official Jia Yi (d. $\left.168 \mathrm{BCE}\right)$, who was tutor to the young Prince of Liang. In one of his famous memorials to Emperor Wen of the Han, one of the issues he discusses is the Han policy toward the Xiongnu tribes on the northern and northwest borders. Minister Yi refers to Yi Yin , who helped King Tang of Shang defeat the Xia. He had advised Tang to test Xia's power by stopping tribute payments; the enraged Xia king summoned the armies of the nine Yi tribes to attack Shang. The Shang king immediately apologized and paid tribute.
} See Shuo yuan ～(Taibei: Shangwu yinshuguan 1988), 13.444.

${ }^{51} \mathrm{Qi}$ and Jin were the two powerful feudal domains in the Spring and Autumn period (771-476 BCE). Duke Huan of Qi (d. 643 BCE) and Duke Wen of Jin (697-628) were known for assuming leadership among the feudal lords to revere the royal house of the Zhou and "expel the Yi and Di [barbarian] peoples." Mencius and Confucius hailed from the states of Zou and Lu, respectively, and so "Zou Lu" became a reference to highly civilized land. 
Yanzhi. Its discursiveness, marked by words such as “ever since” ( $z i$ 自) or "not to mention”

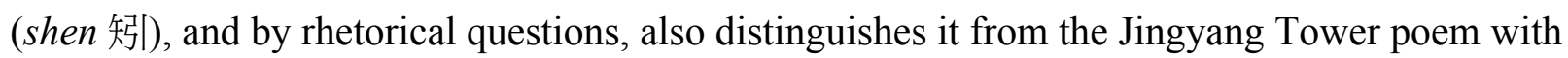
the latter's parallel couplets of scenery depiction that seem more static and ornate. The Jingyang Tower poem also sounds modern because of the deliberate choice of unusual verbs, such as in the fourth couplet. Emperor Wen seems consciously to manipulate his poetic style to suit the occasion of speech and maximize the desired effect on his audience. Indeed, the few references in the preceding poem are all to Shang, Zhou, and Western Han dynasties, their aura of high antiquity befitting the solemnity of imperial proclamation, and implicitly stressing the Han Chinese cultural legacy inherited by the Song and thus the legitimacy of the Song rule. Lines 1314, which portray the imperial poet as feeling compassion for the suffering folk, are effectively performative: by proclaiming himself as the person charged with the kingly responsibility, he represents himself as the true king.

An account of Emperor Wen's arduous performance of kingship would not be complete without mention of his tours of Jingkou京 $\square$. Jingkou, a city to the east of the capital and on the south shore of the Yangzi River, occupied a position of military importance; it was also the hometown of the Liu Song emperors: both Emperor Wen himself and his father, the Song founder Liu Yu, had been born there. In his will and testament Liu Yu stated, "Jingkou is a crucial place, very near to the capital; nobody but close members of the royal house should be stationed there” 京口要地, 去都邑密邇, 自非宗室近戚, 不得居之. ${ }^{52}$ Twice in Emperor Wen’s rule did he visit Jingkou: once in 427, the year after he executed the regents and crushed the armed uprising of one of them; once in 449, after he had ruled for more than two decades.

\footnotetext{
${ }^{52}$ Song shu 78.2019,
} 
The second time he visited Jingkou, the emperor stayed there for more than three months, from March 12 till June 23, and kept a busy schedule. He paid respects to his grandparents' tombs, met with and held a grand feast for "more than ten thousand" former officials and local elders, granted a general amnesty throughout the realm, and reduced by half the taxation to be paid by Dantu county (in which Jingkou was located) as well as the counties that the imperial entourage passed through, and also exempted several commanderies from tax and corvée. The imperial edicts issued at Jingkou are impressive documents in themselves. Referring to Jingkou as the empire’s “northern capital” (beijing 北京), Emperor Wen ordered the relocation of several thousand households to Jingkou, to make the city more populous. In his words, Jingkou was "the hometown to the imperial foundation, not to mention it is located in a crucial position of defense; thus one must make it prosperous so as to ennoble this renowned region”皇基舊鄉，地兼蕃重， 宜令殷阜, 式崇形望. ${ }^{53}$ The historian Shen Yue considers Emperor Wen's Jingkou expeditions as imperial ritual journeys known as xunshou 巡守; he records them in detail both in Emperor Wen's “Annals” and in the "Monograph on Ritual” (“Li zhi” 禮志) of Song shu, and comments with evident disapproval that throughout the preceding Jin dynasty no such imperial ritual inspection tour had been performed. ${ }^{54}$

What concerns us here, again, is not just the royal court's progress itself, but also how it is textually represented to an audience, from the immediate small circle of courtiers attending the emperor, to a much larger elite group in the capital and throughout the realm. As we will see in the next section, he also put his favorite writers to good use on these occasions.

\footnotetext{
${ }^{53}$ Ibid., 5.97.

${ }^{54}$ Ibid., 15.380-81.
} 


\section{The Court Poet Who Imagined and Recreated the South}

Xie Lingyun and Yan Yanzhi were the two most prominent poets of their age. Both men's rise and fall were closely tied to court politics and, in particular, the fortunes of the Song princes. It is well known that, in the early 420s they were exiled because of their association with Liu Yizhen, but it is less often observed that another prince, Liu Yikang, who acted as regent during Emperor Wen's prolonged period of sickness, was responsible for both men's downfall in the 430s. Emperor Wen could not stop Xie's execution, ${ }^{55}$ but he did intervene more actively on behalf of Yan and protected him from Yikang's wrath. ${ }^{56}$ The way in which Yikang treated Xie

\footnotetext{
${ }^{55}$ While Xie Lingyun was serving as Administrator of Linchuan (in modern Jiangxi), he went on pleasure outings at all times and "did not behave any differently from when he was at Yongjia [Xie's earlier place of exile].” It was Liu Yikang who responded by sending his assistant to arrest Lingyun. Lingyun resisted and was subsequently accused of plotting a rebellion, a crime punishable by death. "The emperor cherished his talent, and only wanted to strip him of office; but Yikang, the Prince of Pengcheng, insisted that he should not beexonerated.” Emperor Wen thereupon exiled him to Guangzhou, where he was eventually implicated again and executed in the marketplace. See Song shu
} 67.1777 .

${ }^{56}$ Like Xie, Yan had offended Liu Yikang and his close associate Liu Zhan $\quad$ (392-440). Yikang first exiled Yan to Yongjia, and was going to send him to a place even further when Emperor Wen intervened. Thus Yan was only stripped of his office and stayed at home for seven years. In July of 440, the empress Yuan Qigui (405-440), mother of the crown prince, died, and Yan Yanzhi was commissioned to compose the official dirge (aicewen ). A few months later, Liu Zhan was executed for treason, and a disgraced Yikang was sent away from the capital; almost immediately afterward Yan Yanzhi was reestablished in office. From that point on he remained close to the emperor, serving as the chief court writer, except for an apparently brief period of dismissal from office as a disciplinary action. Song shu 73.1893, 73.1902. 
and Yan bears out the earthy, pragmatic prince's reputation for caring little about cultural matters, and brings into sharp relief Emperor Wen's political vision about a much more articulate and articulated imperial rule. ${ }^{57}$

Both poets had celebrated Emperor Wen's Jingkou tours in verse. Xie's poem, "Attending His Majesty on an Outing to Beigu Hill at Jingkou: Written at Imperial Command" (“Congyou Jingkou Beigu yingzhao” 從遊京口北固應詔), was composed in $427 .{ }^{58}$ It reads as follows:

玉䨝戒誠信 The imperial seal of jade imparts sincerity and trustworthiness, 黃屋示崇高 The yellow canopy demonstrates superior loftiness.

事為名教用 While these objects are utilized by the Doctrine of Names,

4 道以神理超 The kingly Way is transcendent because of divine principles.

昔聞汾水游 We have heard of the outing of Fen River in the past;

今見塵外鑣 Today we witness His steeds beyond the dusty world.

鳴笳發春渚 Sounding wind-pipes set out from the spring shores,

\footnotetext{
${ }^{57}$ Yikang's Song shu biography makes much of his lack of learning and disdain for cultural pursuits. At one point, he reportedly commented on an able administrator Wang Zhunzhi that two or three men like Wang would create the perfect government: "Why do we ever need those lofty discourses on metaphysical principles?" . Interestingly, Wang was once mocked for a poem of his in five-syllable lines by a colleague, who said, "You only know how to write accusations" $\quad$; Song shu 60.1624.

${ }^{58}$ Wen xuan 22.1037-38; Lu Qinli, 1158. For other English translations, see Wu, Written at Imperial Command, 8485, and J. D. Frodsham, The Murmuring Stream: The Life and Works of Hsieh Ling-yün (Kuala Lumpur: Univ. of Malaya Press, 1967), 1: 171.
} 
8 稅鑾登山椒 Stopping the carriages, we ascend to the top of the hill.

張組眺倒景 From the curtained enclosure, we gaze at the hill's reflection in the water;

列筵矚歸潮 Seated at the banquet, we regard the returning tide.

遠巖映蘭薄 Distant cliffs are half-concealed by magnolia groves;

12 白日麗江墓 The river's shore gleams in the white sun.

原隰荑綠柳 The plain is sprouting with green willows;

墟直散紅桃 Through villages and gardens scatter red peach blossoms.

皇心美陽澤 The emperor's heart takes delight in the sunny grace;

16 萬象咸光昭 Myriad things are all illuminated, bathed in light.

顧已枉維槷 Looking upon myself, I am tethered and bound for nothing，

撫志慚場苗 Reflecting on my aspirations, I feel ashamed by the garden's shoots. ${ }^{59}$

工拙各所宜 The skillful and the clumsy each follows what suits him,

20 終以反林巢 As for me, I should ultimately return to my nest in the woods.

曾是縈舊想 How could I be so entangled in an old fancy?

覽物奏長謠 As I view things, I present this long song.

The poem begins with two signs of imperial power, jade seal and yellow canopy, and describes the symbolic significance of each. It goes on, however, to say that although these

\footnotetext{
${ }^{59}$ As Li Shan's commentary points out, this couplet is an allusion to a passage in the Shi jing poem, "White Colt" , Mao 186: "The splendid white colt/Eats the shoots of my garden.// Tether it and tie it,/So as to make this morning last” : $\quad, \quad, \quad$ It is generally taken to be a poem about retaining the service of a worthy man, like the tethering of a fine horse; Mao shi zhushu $\quad, 11.378$.
} 
visible signs are put to use by the Confucian doctrine, what is truly important remains invisibleit is spiritual principles that mark the kingly Way as transcendent. The emphasis on "spiritual principles" continues into the third couplet. As Li Shan annotates, the first line refers to a Zhuangzi passage, which states that the sage emperor Yao, after governing his people well and putting his realm in order, went to see the Four Masters on the north shore of the Fen River, where in a daze he "forgot" about his empire; ${ }^{60}$ the next line, "beyond the dust," also echoes Zhuangzi, which mentions several times that the sage is a man roaming carefree beyond the dust and filth and engaging in the enterprise of "doing nothing." 61 One may be tempted to understand the couplet as advocating a certain vision of kingship, which sees the king as a Daoist ruler achieving good government by not interfering, but more likely Xie is merely praising the emperor in terms that show traces of the influence of the "metaphysical discourse" and "metaphysical poetry" so popular in the fourth century.

The fourth though eighth couplets depict first the imperial progress and then the activities and the view from the hilltop. Lines 15-16 turn back to the emperor, whose grace is compared to the sun bringing a myriad images into bright manifestation. This leads to the poet's looking upon himself, who is, as the subtext indicates, a "splendid white colt" likewise illuminated by the imperial sun and detained at the court, but he insists that he does not deserve the fine emolument being offered him. What he wants to be is a bird, flying back to his nest in the woods, much like the "returning tide." The longing to go home is "an old fancy," stirred by viewing the spring landscape.

\footnotetext{
${ }^{60}$ Zhuangzi jishi ， ed. Guo Qingfan ～(1844-1896) (Beijing: Zhonghua shuju, 1961), 1.6.

${ }^{61}$ See the "Dazongshi” $\quad$ and "Dasheng" $\quad$ chapters; Zhuangzi jishi 3A.268, 7A.663.
} 
Xie's is a competent poem, but there is a slight oddity about the concluding lines that, taking up one third of the poem, sound a little too earnest about retirement. One also wonders how Emperor Wen might feel toward the opening couplets protesting the importance of "spiritual principles" and subtly downplaying the visible, physical signs of imperial power. If we look at Yan Yanzhi's poems written on the emperor's second Jingkou tour, we will see a profound difference.

One of the poems was composed on the imperial outing to the Rear Lake of Qu'e in observation of the Lustration Festival (April 11, 449). ${ }^{62}$ The poem begins with a familiar citation of precedents from antiquity, thus establishing a venerable tradition for the current royal journey:

虞風載帝狩 Yu’s airs give account of the monarch's journey;

夏諺頌王遊 The Xia proverb praises the king's outing. ${ }^{63}$

春方動辰駕 Toward the sector of spring Polaris moves its chariot， 4 望幸傾五州 And all five provinces yearn for the grace of the imperial visit.

\footnotetext{
${ }^{62}$ The poem is entitled "Composed as I Accompanied His Majesty on an Outing to the Rear Lake of Qu'e on the Third Day of the Third Month during the Imperial Visit to Jingkou” (“Chejia xing Jingkou sanyue sanri shiyou Qu'e houhu zuo" ). Lu Qinli, 1231. Wen xuan 22.1054-55. For another English translation, see Harding, 218-19.

${ }^{63}$ As Li Shan notes, Emperor Yu Shun went on an inspection tour eastward in the second month of the year (“Canon of Shun” , Shangshu zhushu , 3.38); Mencius cited a Xia saying, "If our King does not go on a tour,/ How can we get to rest from our toil?// If our King does not go on a journey,/ How can we receive sustenance?// Our King's tour, our King’s journey/ Will set a model for the noble lords" , , ? , ? $\quad$, Mengzi 1B.4; Mengzi zhushu $\quad$, 2A.33.
} 
If the first couplet contextualizes the emperor's outing from a temporal perspective, the second couplet transitions to an intricate verbal configuration of space. Spring, the season of the present outing, in Chinese cosmology represents the east because, as a Han commentator notes, the Northern Dipper's handle pointing to the east signifies spring. ${ }^{64}$ Since an emperor is traditionally referred to as the North Star, in this case Emperor Wen's spring travel to Jingkou to the east of Jiankang accords perfectly with the movement of the heavenly bodies and indeed seems to have brought about the arrival of spring. The five provinces in the next line refer to the northern provinces not under the Song dynasty's control, whose people look to the imperial perambulation with envy and longing. In an ingenious rhetorical move, Yan Yanzhi turns a negative political reality— that north China was outside of Song's domain —into an advantage. This is the same ingenuity we have witnessed earlier in his representation of the winter harvest.

The next four couplets demonstrate a technique that might be called alternating progression, as each couplet is constituted of one line about land and one line about water (a practice also seen in Xie Lingyun's landscape poetry), and the couplets collectively represent a temporal progress in juxtaposition. The first couplet below describes how gods and spirits prepare for the imperial visit; the second couplet is a straightforward linear depiction of the emperor's emerging from the carriage and embarking on the boat; the next two describe the splendor of the imperial procession on land in the first line and the spectacle on water in the second.

\footnotetext{
${ }^{64}$ He Xiu's (129-182) commentary on Gongyang zhuan : "When the Dipper['s handle] points to the east, it is spring” $\quad$ Gongyang zhushu $\quad, 1.8$.
} 
山祇踶嶠路 Mountain deities clear the road in the hills; ${ }^{65}$

水若警滄流 The water-god Ruo stands guard over blue currents.

神御出瑤軫 The divine rider alights from the jade-adorned carriage;

8 天儀降藻舟 The heavenly visage descends to the painted boat.

萬軸能行衛 Imperial guards in myriad chariots proceed one after another;

千翼汎飛浮 A thousand wings speed forward on the waves.

彫雲麗玫盍 Colorful clouds surround the canopy bedecked with carnelian;

12 祥䫻被綵斿 Auspicious wind blows multi-hued streamers.

If the couplets above depict the imperial entourage in motion, then the next eight lines portray the feast scene as well as the view from the site of the banquet:

江南進荆豓～River's South: Jing's ballads are proffered;

河激獻趙謳 Watercourse Rapids — the Zhao ditty is presented. ${ }^{66}$

金練照海浦 Golden armor and battle-robes of raw silk illumine the strands of the sea;

\footnotetext{
${ }^{65}$ Li Shan cites Guanzi about a mountain spirit called Yu'er that would manifest itself in front of an overlord and ride fast ahead to lead the way; Wen xuan 22.1055. But the shanchi here could also be a general reference to mountain deities.

${ }^{66}$ Li Shan cites the story from Liu Xiang's (79-8) Lienü zhuan about a ford official's daughter who sang the song "Watercourse's Rapids" to the lord of Zhao to save her father from trouble; the lord of Zhao was so pleased with her that he pardoned her father and made her his wife.
} 
16 笳鼓震溟洲 Reed pipes and drums shake the isles and deeps.

貌盼覯青崖 The expansive view takes in blue cliffs;

衍漾觀綠疇 A flowing gaze observes the green fields.

人靈騫都野 Humans and spirits in city and wilderness lift their heads;

20 鱗翰㣮淵丘 Scaled and feathered beings swim or fly up from rivers and hills.

In lines 13-14, both songs_- "Jiang nan" and "He ji" — are no doubt performed by the southern court musicians, but the names are syntactically embedded in such a way that they can also be construed as referring to geographical regions: i.e., "From the south of the Yangzi, Jing ballads are proffered; / From the rapid River a Zhao ditty is presented." The couplet thus brings together south and north that are respectively represented by Yangzi/Jing of southern China and Yellow River/Zhao of northern China, and by making the emperor the recipient of the northern and southern music, it makes him the center.

Lines 17-18, with their emphasis on land (cliffs and fields), balance the preceding couplet with its stress on water, but form a coherent unit of meaning with the following couplet because Yan Yanzhi again employs the "shifting viewpoint" device, moving from the imperial view to the people, spirits, and animals' eager upward gaze at the imperial splendor. ${ }^{67}$ The emperor both looks and is being looked at: this is a perspective that only the third party — the court poet present — could assume and represent, and this is precisely why the latter occupies such an important position in the configuration of the court and empire. Lines 19-20 lead to the conclusion of the poem:

\footnotetext{
${ }^{67}$ I disagree with Li Shan's annotations of qian and song as "startled and afraid" . . Rather, qian has the meaning of raising one's head; song has the meaning of moving or leaping upward.
} 
德禮既普洽 Now that virtue and rites have spread everywhere, 川嶽徧懷柔 Rivers and mountains are all mollified.

The last line, as Li Shan notes, is a reference to the Shi jing poem, “Shi mai” 時邁 (Mao 273), praising the Zhou king's inspection tour for "attracting and mollifying all deities/ Even [the gods of] the [Yellow] River and the great Mount [Tai]” 懷柔百神, 及河喬嵓. ${ }^{68}$ By changing the word "He" 河 (i.e., Yellow River) to the more general chuan ॥, Yan also implicitly changes the meaning of yue 嶽 from its specific designation to the more general "mountain." The point is that while the poem still resonates with the venerable classic, it also expands its realm of reference to a much larger circumference than Zhou's domain, which was largely confined to the Chinese heartland in the north.

The representation of kingship and empire reaches its height of perfection in Yan's other poem written at Jingkou, a tour-de-force performance by the veteran poet. The poem is entitled "Composed upon Accompanying His Majesty on an Outing to Onion Hill during the Imperial Tour to Jingkou” (“Chejia xing Jingkou shiyou Suan shan zuo” 車駕幸京口侍游祘山作). ${ }^{69}$

Onion Hill is so named because of the wild onions growing on it; it is a flat-topped little hill overlooking the Yangzi River.

元天高北列 Primordial Heaven towers amidst the array of northern stars;

\footnotetext{
${ }^{68}$ Mao shi zhushu 19.719.

${ }^{69}$ Wen xuan 22.1051-53. Lu, 1231. For other English translations, see Harding, 223-24; Wu, 93.
} 


\begin{abstract}
日觀臨東溟 The Sun-viewing Peak overlooks the Eastern Sea.
入河起陽峽 Going down the River one sees the Yang Mountains rising;

4 踐華因削成 From its knife-pared cliffs one ascends Mount Hua.
\end{abstract}

The first couplet, instead of the customary Yan Yanzhi introduction of historical precedents, establishes a subtly structured spatial scene. Primordial Heaven is the name of a mythical mountain in a now lost version of Zhuangzi; according to Li Shan's quotation, the mountain is so high that one can see "arrays of stars on all four sides," though the poet noticeably stresses "northern" constellations. The mention of the heavenly bodies leads to the next line, which begins with "sun-viewing"- the name of the southeastern peak of Mount Tai overlooking the ocean. The opening couplet thus presents a majestic picture of heaven and earth, mountain and sea, complete with the movement of rising up and looking down.

Mount Tai provides the link between the first and second couplet, as Mount Tai and Mount Hua are both described elsewhere as being so steep that they look like having been pared by a knife. ${ }^{70}$ The second couplet is built around two landmarks in the north—-the Yellow River and Mount Hua - and one textual reference, namely to Jia Yi's "Discourse on Faulting the Qin" (“Guo Qin lun” 過秦論). Li Shan, as he often does, only cites one directly relevant line as the source, but the entire passage from Jia Yi's famous treatise is the subtext: "Thereafter [the first Qin emperor] ascended Mount Hua as his city-wall, and turned the Yellow River into his moat; he thought that he could thus enjoy the security of a city-wall a myriad feet tall and the channel

\footnotetext{
${ }^{70}$ Li Shan quotes Shanhai jing $\quad$ : "Mount Tai and Mount Hua seem to have been carved by a knife on their four sides"
} 
of immeasurable depth” 然後踐華為城, 因河為池, 據億丈之城、臨不測之谿以為固. ${ }^{71}$ “Yang xia” 陽峽 could mean several different things, ${ }^{72}$ but the point of the couplet is clear: the poet is speaking of the use of famous sites as natural defenses of Xianyang, the capital of the Qin empire. These opening lines conjure up a majestic landscape in the north. Then a dramatic shift occurs:

嚴險去漢宇 The steep defiles had long since left the Han realm;

祈衛徙吳京 The collar-and-girdle defenses have moved to the Wu capital. ${ }^{73}$

流池自化造 The flowing moat was originally fashioned by the Creator;

8 山關固神營 The mountain passes are truly the work of gods.

${ }^{71}$ Shi ji $\quad$ (Beijing: Zhonghua shuju, 1959), 48.1963; Wen xuan 51.2236.

${ }^{72}$ Li Shan believes xia stands for xia , and cites the Eastern Han commentator Wang Yi’s (fl. mid-2nd century) gloss of xia as "hillside," quoting from a Shi ji passage to identify Yangxia as the Yang Mountains (modern Langshan in Inner Mongolia). The Qin general Meng Tian ， commanded to build the Great Wall, "crossed the Yellow River and occupied the Yang Mountain" （Shi ji 88.2566). While this interpretation corroborates the couplet's allusion to Jia Yi's treatise on the Qin empire, the philological evidence offered by Li Shan does not seem entirely sound, because the xia glossed by Wang Yi as "hillside" is only applicable to the specific context in which it occurs, as part of the phrase, shan xia , literally the valley between the hills. I suspect that, parallel to "pared by a knife" in the corresponding position in the following line, yang xia is simply "sunny gorge." It might refer to the Three Gates Peak ～～(better known as Dizhu shan ， Stone Pillar Peak, near the modern city Three Gates Gorge in western He'nan bordering on Shaanxi province). The line could be rendered as "Entering the River one sees the sunny gorge rising."

${ }^{73}$ Yanxian and jindai are terms used in the Eastern Han writer Zhang Heng's (78-139) "Western Metropolis Rhapsody" ～(see Li Shan's notes in Wen xuan 22.1052) and "Eastern Metropolis Rhapsody" . 
By juxtaposing "Wu capital" with "Han realm," the poet is implicitly claiming a much grander status for "Wu"- both the Kingdom of Wu that first made Jiankang an imperial capital and also the region itself - than it had ever assumed up to this point. Most remarkably, the poet literally moves the mountains and rivers of the north to the south, asserting that the precipitous defenses have all relocated to Jiankang. He is, of course, speaking of the Yangzi River and Onion Hill that act as naturally-formed defenses for the capital. Zao and ying, applied here to the Creator's fashioning of the terrain, are verbs indicating artificial construction and craftsmanship, and in a way perfectly describe the poet's own Herculean accomplishments in his poetic transportation of topography.

園縣極方望 In the mausoleum county sacrifices are made to the entire spectrum of deities;

邑社㧾地靈 Upon the altar of the sepulcher town, all earth gods enjoy the offerings. ${ }^{74}$ 宅道炳星緯 The territories of the imperial residence are illuminated by stellar constellations;

12 誕曜應神明 The birth of radiance corresponds to Divine Brilliance. ${ }^{75}$

\footnotetext{
${ }^{74}$ In the Han a residential area, known as lingyi , mausoleum towns, would be formed beside an imperial mausoleum to watch over it.

75 "Divine Brilliance" is a reference to the sun; see Zhang Yan's (fl. late 2nd-early 3rdcentury) commentary in Shi ji 28.1382.
} 
After extolling the landmarks of Jingkou as natural defenses, the poet proceeds to describe the city's importance as the ancestral home of Song emperors. At Jingkou were the tombs of Emperor Wen's grandparents, to which the emperor paid respects every time he visited; he also made offerings to deities and spirits of all directions and the earth gods, an imperial ritual through which the emperor demonstrated and confirmed his legitimacy. The description of Jingkou thus proceeds from its natural environs to the resting place of the royal ancestors in its suburbs, and then zooms in to the imperial residence in the city, where the current emperor was born. Noticeably, lines 11-12 subtly parallel the opening couplet of the poem in its juxtaposition of stars and sun: not only have the natural defiles and strongholds of the north relocated to the south, but the heavenly bodies too are manifesting their splendid aura over the southern territories.

The next three couplets turn to the emperor's outing:

睿思纏故里 Sagacious thoughts linger over the native place;

巡駕币舊㭣 The imperial carriage circles the familiar suburbs.

陟峰騰輦路 Scaling the peak, the route of the royal palanquin soars;

16 尋雲抗瑤瞢 Seeking clouds, the corner eaves of jade turn upward.

春江壯風濤 On the spring river surge powerful wind-blown waves;

蘭野茂稊英 Over the lush plain, plants are sprouting and budding.

The emperor's fond thoughts "winding around" his hometown are in parallel with the carriage's circular motion; this horizontal movement is then counterbalanced with the vertical progress of the next couplet. In the second couplet, teng 騰 and kang 抗 describe respectively the 
rising of the carriage road and of the upturned corner eaves, the latter sometimes called "soaring eaves” 飛瞢; but they also describe human actions — the entourage ascends (teng) to the peak on the royal carriage road, and the view, following the clouds, necessarily goes beyond the uppointing eaves. Kang here is particularly well-chosen because its multiple meanings co-exist in the interpretation of this line: the elevated eaves with their up-pointing shape seem to "resist" or "support" the clouds and human vision seems to "match" the elevated eaves in following the clouds. This couplet showcases Yan Yanzhi’s remarkable poetic craftsmanship.

The third couplet of water/land offsets the upward movement by describing the downward gaze from the hilltop. The river swells with spring tides; the plain is lush with spring plants. This scene of growth and prosperity leads to the next couplet, which credits the royal perambulation with the conferral of imperial favor and grace on all below, and the emperor's affection for his former home is now shown to expand to the "farthest regions" of the empire:

宣遊弘下濟 With far roaming, imperial grace is widely propagated below;

20 窮遠凝聖情 His sagely feelings are focused on the farthest regions.

獄濱有和會 All come to the joyful assembly on the hill,

祥習在卜征 Auspicious portents having abounded in repeated divinations about the journey. $^{76}$

\footnotetext{
${ }^{76}$ Chunqiu Zuo zhuan zhushu 32.556, Duke Xiang 15: "The former kings divined for their inspection tour for five years in a row; if each year an auspicious portent was obtained and the portents were repeated five years in a row, then the king went on the journey"
} 
Lines 21-22, as Li Shan notes, echo the classical tradition. The phrase yue bin 嶽濱

evokes the Guo yu 國語 statement about feudal lords submitting to the authority of Duke Huan of Qi after his successful military campaigns; he hui 和會 alludes to The Book of Documents:

“The people of all four directions came to the great joyful assembly [at Luoyang]” 四方民大和 會. ${ }^{77}$ This assembly took place in the city of Luo newly created by the Duke of Zhou. Later, after the fall of the Western Zhou, Luoyang became the capital of the Eastern Zhou. The resonance with the situation of the southern dynasties —-with Jiankang as the capital of the Eastern Jin, after the fall of Western Jin, and now also of the Song - is inescapable. It is this subtext of the Zhou rule that is picked up in the next line, in the concluding stanza of the poem.

周南悲昔老 In the past the old man to the south of the Zhou capital grieved, 24 留滯感遺讯 Moved by how he remained, having been left behind;

空食疲廊肆 But I, with my sinecure in court, have fallen prey to fatigue:

反稅事嚴耕 I would like to go home for relief, plowing beneath the cliffs. ${ }^{78}$

\footnotetext{
${ }^{77}$ Guo yu (Shanghai: Shanghai guji chubanshe, 1978), 6.242: "None of the noble lords from the Mountain region dared not come in submission” _ ;Kang gao" ， in Shangshu zhushu 14.200.

${ }^{78} \mathrm{Li}$ Shan glosses shui as tax and seems to suggest that poet hopes to pay his tax by farming (i.e., retiring from office); but fanshui is not used to describe paying tax in the early medieval period. I take shui here as meaning "to rest," as in Cao Zhi's (192-232) "Poem Composed to the Imperial Command" : : "I rest under the western wall" ; $\quad$ Lu, 447. It also means "to free and release," and can describe relieving a domestic animal from yoke or a person from confinement.
} 
The phrase Zhou nan 周南 in line 23, literally “south of the Zhou capital," refers to Luoyang, and the old man grieving in Luoyang is identified by Li Shan as the court astrologer and historian Sima Tan 司馬談 (d. 110 BCE). Sima Tan was unable to follow Emperor Wu of the Han on his journey to perform the fengshan ceremony at Mount Tai, and, according to his son Sima Qian's 司馬遷 (ca. 145-87) account, he was so dismayed that he fell ill and died. ${ }^{79}$ Many commentators, beginning with Li Shan, take this allusion to mean that Yan Yanzhi did not actually get to follow Emperor Wen on his tour. I side with Chen Zuoming 陳祚明 (1623-1674), who believes that the poet was indeed among the emperor's entourage and that he cites Sima Tan as a contrast with himself. In other words, Yan is saying that unlike Sima Tan, he is fortunate in partaking in the emperor's progress, but he feels embarrassed that he is receiving a salary for nothing. ${ }^{80}$ This modesty is undercut by the phrase "plowing beneath the cliffs," which betrays Yan Yanzhi's infamous pride. ${ }^{81}$ Li Shan rightly cites the passage about the Western Han recluse Zheng Zizhen 鄭子真 (fl. first century BCE): “He plowed beneath the cliffs, but his name was well-known through the capital” 耕於嚴石之下, 名震乎京師. ${ }^{82}$ The context of the reference, which Li Shan habitually fails to give, is Yang Xiong's contention that royal princes could not attain immortal fame through prestige and power, but a man of virtue could.

\footnotetext{
${ }^{79}$ Shi ji 130.3295 .

${ }^{80}$ Chen Zuoming, Caishu tang gushi xuan (Shanghai: Shanghai guji chubanshe, 2008), 16.507.

${ }^{81}$ Yan Yanzhi was known for his arrogant, fiery temperament and bluntness in speech, intensified by wild drinking. See his Song shu biography.

${ }^{82}$ Yang Xiong (53 BCE-18 CE), Fayan yishu ， ed. Wang Rongbao (Beijing: Zhonghua shuju, 1987), 8.173; also cited in Han shu ～(Beijing: Zhonghua shuju, 1962), 72.3098.
} 
Thus it would seem that the poem has an interesting ending, establishing by contradistinction a connection between a court astrologer who had begun a great work of history and the poet who also endeavored to represent a grand account of his court and dynasty, albeit in verse. The imperial glory embodied in the poem is subtly intertwined with aspirations for personal glory; nevertheless, when Yan Yanzhi's small elite audience, in particular the emperor himself, read the poem, what stands out in the concluding stanza would surely be, first of all, the nature of the imperial journey Sima Tan was so pained to have missed: it was a journey performed by the most powerful ruler of the long-lasting Han empire - the legendary Emperor $\mathrm{Wu}$ - to pay homage to Heaven and Earth in the Fengshan sacrifices on sacred Mount Tai. With this subtext, the poem circles back to its majestic opening couplet about Mount Tai’s Sunviewing Peak, although the emphasis on the humble recluse plowing beneath the cliffs forms a sharp contrast with the Primordial Heaven Mountain towering above the stars. Nevertheless, Yan Yanzhi's turn to the unfortunate subject left behind by the Han emperor and to the subject determined to be a recluse only serves to accentuate the grandeur of the monarch and the greatness of the empire, which includes and contains all sorts of people in it. ${ }^{83}$

If we compare the endings of this poem and Xie Lingyun's poem discussed above, we note a remarkable similarity in that both speak of the poet's feeble abilities and desire to return to private life; but Yan Yanzhi is much less obtrusive about it, and even in speaking of himself, he makes sure to foreground the glory of the current dynasty by implicitly comparing it with the great Han. Yan Yanzhi's works especially exemplify what court poetry is and they set a model for what court poetry should be: it is not about one's private concerns, but about representing

\footnotetext{
${ }^{83}$ The necessity of recluses in a dynasty — a sign of the ruler's tolerance—-is well demonstrated by the installment of a "fill-in recluse" (chongyin ) according to the usurper Huan Xuan's ～(369-404) order; Jin shu 99. 2593-94.
} 
kingship and empire. Thus it is a form of gross anachronism to accuse it of lacking individuality or self-expression. Our modern notions of the individual and of self-expression are much later constructs that have no bearing on early medieval society. By its very nature a court poem is not private, but it is entirely personal for a courtier whose identity was bound to the court he belonged to and whose selfhood could not be separated from his sense of aristocratic identity.

However a modern reader might feel about the evocation of the massive and magnificent northern mountains like Mt. Hua and Mt. Tai in depicting a small hill overgrown with wild onions, one must acknowledge the artful mastery of the senior court poet. In a bold act of imagination, he represents the southern empire in a regal style. Scholars have discussed Yan Yanzhi's innovative use of allusions, ${ }^{84}$ but much more important than his rhetorical maneuvers is his capacity for imagining and constructing the empire. The sixth-century critic Zhong Rong 鍾 嶸 (d. 518) was right in saying that "his was the kind of talent that suited the cultural purposes of the state” 是經綸文雅才. ${ }^{85}$ Yan Yanzhi's poetic vision recreates the south. In this sense, he was the first true court poet of the Southern Dynasties.

\section{"The Province of Emperors and Kings"}

Emperor Wen's physical and textual construction of Jiankang as the great capital was continued in the reign of his son, Emperor Xiaowu, and later intensified in the second half of the

\footnotetext{
${ }^{84}$ The best work about Yan Yanzhi regarding his use of allusions, and the only monograph on him in Chinese, is Chen Dongbiao's Yan Yanzhi yanjiu (Changsha: Hu'nan renmin chubanshe, 2008).

${ }^{85}$ Shi pin jizhu $\quad$, annot. Cao Xu . (Shanghai: Shanghai guji chubanshe, 1994), 270.
} 
fifth century, in the court of the Southern Qi 齊 $(479-502) .{ }^{86}$ In the course of a little more than a century, the city became a showpiece and emblem of the southern empire, with its imperial magnificence matched by cultural splendor.

Although Qi’s founding emperor, Gaodi 高帝 (r. 479-482), was not on the throne for long, he was remarkably attentive to the building of Jiankang. In the Southern Dynasties, on New Year's Day a cask of wine that had a lid decorated with a white tiger would be publicly set up, and anyone who wanted to offer candid criticism to the emperor could drink from it. ${ }^{87}$ On New Year's Day of 480, the criticism offered to the emperor by a man drinking from the white tiger cask was a rhymed saying: "The White Gate is locked three-fold. / The palisade is all broken and full of holes” 白門三重關, 竹篗穿不完. ${ }^{88}$ The “White Gate” was the popular name for Xuanyang Gate宣陽門, the main gate to the south of the capital. The target of the irony here is the wood-and-bamboo palisade outside the city of Jiankang, which up to this point had yet to have a brick-and-mortar city wall. As the saying implies, although the White Gate is carefully locked, the city is not secured because of the dilapidated palisade. Much stirred by this saying, the emperor commissioned the construction of a proper city-wall. Earlier, Gaodi had planned to

\footnotetext{
${ }^{86}$ Emperor Xiaowu was a frenetic builder. He constructed Zhengguang $\quad$ Palace and a Confucius temple in 454; established a Shanglin Park to the north of Xuanwu Lake in 459; built a ritual hall and opened two imperial boulevards in 461 ; constructed an Ice Chamber as well as created a new city gate called Dahang Gate in 462. See Song shu 114-29. Emperor Xiaowu was also well known for his fondness of poetry. His own compositions were originally left as a large literary collection in thirty-one juan (one of which was a table of contents), out of which twenty-five juan were still extant in the early seventh century; Sui shu 35.1071. Quite a few poems by him are still preserved, mostly from encyclopedia sources; see Lu Qinli, 1218-24.

${ }^{87}$ Song shu 14.345.

${ }^{88}$ Nan Qi shu 23.434-35.
} 
rebuild Xuanyang Gate, but was persuaded by his officials to drop the plan. ${ }^{89}$ Now the prime minister Wang Jian 王儉 (452-489) again protested the idea, but this time the emperor stood his ground, saying, "“I want later generations to have no way to surpass this [by building something more magnificent]"” 吾欲令後世無以加也. ${ }^{90}$ Here the emperor was citing the words of Xiao He 蕭何 (257-193 BCE), grand chancellor of the founding emperor of the Han; the emperor had once angrily criticized Xiao He for his excess in palace construction, to which Xiao He answered: "The Son of Heaven takes the entire land within the four seas as his home; without a magnificent dwelling, he could not manifest his majesty. This will also prevent later generations from surpassing it." Xiao He, it should be noted, was considered the ancestor of the Qi emperors, also surnamed Xiao. The construction of a city wall for Jiankang opened an important new chapter in the history of the great city.

Gaodi's successor, Emperor Wu 武帝 (r. 482-493), ruled over a prosperous empire at peace. Fond of grand court spectacles, through his brief reign he conducted many ritual observances such as the plowing ceremony (jitian 藉田) and martial exercises (jiangwu 講武); on one of the occasions the people of the entire capital came out to look, and the emperor bestowed on all food and drink. ${ }^{92}$ He initiated many building projects: the Palace of Blue Creek 青溪宮 (also called the Old Palace, Jiugong 舊宮), rebuilt on the site of his birthplace beside

\footnotetext{
${ }^{89}$ Gaodi planned to destroy the Palace of Purple Tenuity $\quad$ constructed by Emperor Ming of the Song (r. 465472) and to recycle its building material to build a new Xuanyang Gate. Several ministers sent in a flurry of memorials to the throne in protest, and the emperor gave in. Ibid., 23.434, 28.526.

${ }^{90}$ Ibid., 23.435.

${ }^{91}$ Shi ji 8.386 .

92 This was the martial exercise held on October 27, 491; see Nan Qi shu 3.59.
} 
Jiankang's Blue Creek in $484 ;^{93}$ the Autumn Wind Lodge (Shangbiao guan 商㜄館) on the Sun Mausoleum Hill (Sunling gang 孫陵崗) in $487 ;{ }^{94}$ the Xinlin Park 新林苑 in $487,{ }^{95}$ and Xingguang Tower 興光樓 painted with blue lacquer, and thus referred to by people in the capital as the "Blue Mansion" 青樓. ${ }^{96}$ Keenly aware of the ephemeral nature of these constructions, in his will and testament the emperor specifically left words about three of the palaces, Fenghua 鳳 華, Shouchang 壽昌, and Yaoling 耀靈, all erected in his reign:

For the One who rules over the world and possesses the riches of the four seas, his dwelling place, where he rests and relaxes, cannot be lowly and humble. I consider these [palaces] as reaching the middle ground between luxury and frugality. They must not ever be destroyed. ${ }^{97}$ 夫貴有天下, 富兼四海, 宴處寢息, 不容乃陃. 謂此為奢儉之中, 慎勿壞去.

Knowing that even more lasting monuments are built with words, the emperor commissioned his courtiers to compose poetry at many of the court feasts. Sui shu's Bibliography section records two titles that bear evidence to these public compositions: The Banquet Poetry of the Qi (Qi yanhui shi 齊讌會詩) in seventeen scrolls; Poetry of the Blue

\footnotetext{
${ }^{93}$ Ibid., 3.48-49.

${ }^{94}$ Ibid., 3.54 .

${ }^{95}$ Ibid., 3.54 .

${ }^{96}$ Ibid., 7.104 .

${ }^{97}$ Ibid., 3.62.
} 
Creek (Qingxi shi 青溪詩) in thirty scrolls, with an attached note, "Composed at Qi banquets." 98 The latter would certainly have included the poems composed at the banquet held at the newly renovated palace on September 11, 484 .

In contrast with the military confrontations in earlier decades, this was a time of truce with the Northern Wei dynasty. In 484, Emperor Wu received a northern mission led by $\mathrm{Li}$ Daogu 李道固 (courtesy name Li Biao 李彪, d. 501) aboard a ship on the Xuanwu Lake during a martial exercise — certainly a deliberate gesture to demonstrate the might of the southern navy. Since then, the north and south entered an era of peace, with diplomats going back and forth every year. ${ }^{99}$ In 491 the northern court dispatched Jiang Shaoyou 蔣少游 (d. 501) as Li Daogu’s vice-envoy. Shaoyou, a man of engineering and architectural skills and the Wei dynasty's Chamberlain for Palace Buildings (Jiangzuo dajiang 將作大匠), was believed to have been entrusted with the task of studying the design of Jiankang's palaces. A courtier Cui Yuanzu 崔元 祖 even sent a memorial to the throne advising the emperor to detain Jiang Shaoyou, arguing, “How could we let the land of felt yurts emulate the image of heavenly palaces”豈可令氈鄉之 鄙取象天宮? ${ }^{100}$ Emperor Wu rejected the proposal for fear of hurting diplomatic relations between the two states, but "Shaoyou indeed sketched [the designs of the Jiankang palaces] and took them home."101

\footnotetext{
${ }^{98}$ Sui shu 35.1084 .

${ }^{99}$ Nan Qi shu, 57.989.

${ }^{100}$ Ibid., 57.990.

${ }^{101}$ Nan shi 47.1173 .
} 
In this year, the celebrated poet Xie Tiao 謝朓 (464-499), Xie Lingyun's clansman, wrote a “Song of Coming to Court" (“Ruchao qu” 入朝曲). The poem is one of a set of ten "Songs for Fife and Drum” 鼓吹曲, commissioned by the young Prince of Sui 隨王, Xiao Zilong蕭子隆 (474-494). ${ }^{102}$ The military orchestra of fife and drum, playing on horseback in a procession, was granted to princes and high-level officials as a special honor. The poem describes how a prince comes to court from the province. Just as the song itself may be performed over and over again as part of a procession, the content of the song is not about a real experience but describes a ceremony. ${ }^{103}$ It is a famous celebration of the royal prince, of the capital city Jiankang, and of the southern empire.

江南佳麗地 Jiangnan is a lovely land,

金陵帝王州 Jinling the domain of emperors and kings. ${ }^{104}$

逶迆帶綠水 Winding off, sashed by green waters,

迢遞起朱樓 Far away there rise crimson mansions.

飛夢夾馳道 Soaring eave-tiles line the Imperial Way,

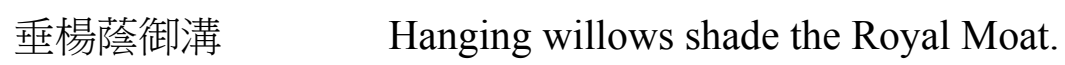

凝笳翼高蓋 Drawn-out notes of pan-pipes flank the high canopy;

$\overline{{ }^{102} \text { Wen xuan 28.1331; Lu Qinli, } 1414 .}$

${ }^{103}$ According to one source, Xie Tiao had composed this set of songs when he was accompanying the prince to go to the prince's post as Governor of Jingzhou (in modern Hubei). Guo Maoqian ～， comp. Yuefu shiji ～(Beijing: Zhonghua shuju, 1979), 20.293; Xie Xuancheng ji jiaozhu_ ， ed. Cao Rongnan ～(Shanghai: Shanghai guji chubanshe, 1991), 2.454.

${ }^{104}$ Jinling is another name for Jiankang. 
疊鼓送華輈Ｓteady drum-rolls escort the splendid axels.

獻納雲臺表 A presentation of memorial on Cloud Terrace- ${ }^{105}$

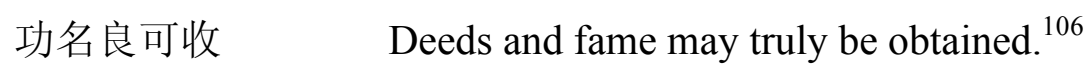

Like premodern Chinese architecture, classical Chinese poetry recycles its building material. Just as Qi's founding emperor had wanted to reuse the beams of Song's palace to rebuild Xuanyang Gate, Xie Tiao bases his opening couplet on an earlier couplet by Cao Zhi that praised Chang'an: "How majestic, the dwelling of an emperor and king!/ Its loveliness distinct from all other cities” 壯哉帝王居, 佳麗殊百城. ${ }^{107}$ Yet, there is a significant difference: in Xie Tiao's couplet, "it is not just a city that is lovely, but all Jiangnan," the "new imperial heartland."108 No other couplet brings out the new significance of Jiankang so succinctly and clearly.

As Owen's analysis shows, this poem's linear progression imitates the prince's progress toward the political center. In the second couplet, the city's skyline seen from afar; in the third,

\footnotetext{
${ }^{105}$ Cloud Terrace was where the Han emperor Mingdi $\quad$ (r. 57-75) had portraits of twenty-eight accomplished generals hung.

${ }^{106}$ Stephen Owen's translation with slight modifications, in "Jiangnan from the Ninth Century On: The Routinization of Desire," in Southern Identity and Southern Estrangement in Medieval Chinese Poetry, ed. Ping Wang and Nicholas Morrow Williams (Hong Kong: Hong Kong Univ. Press, 2015), 189-90. For another English translation, see Richard B. Mather, The Age of Eternal Brilliance: Three Lyric Poets of the Yung-ming Era (483-493) (Leiden: Brill, 2003), 2: 64-65.

${ }^{107}$ Li Shan's commentary cites the couplet; Wen xuan 28.1331. It is from Cao Zhi’s poem, “To Ding Yi and Wang Can” $\quad$, also included in Wen xuan 24.1121.

${ }^{108}$ Owen, "Jiangnan from the Ninth Century On," 190.
} 
the straight boulevard leads one's view, movement, and attention directly to the palace city; in the fourth, the meta-reference to the drum-and-fife music also guides the movement of the prince and his entourage; the last couplet focuses on the ultimately desired destination, namely Cloud Terrace, where a memorial detailing the prince's accomplishments is presented to the emperor and, in exchange, the portrait of the prince will be hung. Just as the economy of presenting (xian 獻) and obtaining (shou 收) achieves a balance in the last couplet, so do the written representation of the prince's accomplishments and the visual representation of his visage. In the end, the prince who goes from periphery to center gets to stay there forever - not in the flesh, but as a painted image.

The depoliticized lovely Southland may be the focus of later poets, but it was the "province of emperors and kings" that was in the foreground of the Southern Dynasties court poets' attention. Around the time when Xie Tiao praised Jiankang in his "Song of Coming to Court," Shen Yue, who along with Xie Tiao was considered the best court poet of the late fifth century, composed an interesting set of five poems on "Outing to Mount Zhong: Written at the Prince of Xiyang’s Command” (“You Zhongshan shi ying Xiyang wang jiao” 游鍾山詩應西陽 王教). ${ }^{109}$ The set should be read as a coherent whole, as one poem of five stanzas, with the first piece illustrating the symbolic significance of Mt. Zhong, which is to the north of Jiankang:

${ }^{109}$ Wen xuan 22.1059-61; Lu Qinli, 1632-33. For another English translation, see Mather, Age of Eternal Brilliance, 1: 5-8. Li Shan identifies the Prince of Xiyang as the Song prince Liu Zishang (450-465). However, I suspect that this prince was the Qi Prince of Xiyang, Xiao Ziming (479-495). Liu Zishang was Prince of Xiyang from 456 to 461 . Shen Yue was an unknown young man in 461 who was just starting his official career as an Audience Attendant, an honorary title that was held by numerous aspirants; soon he went to serve as Record Keeper under Cai Xingzong (d. 472), who seemed to be the only high-level official appreciating his talent, until Cai's death. Only beginning in the early 480s did Shen Yue enjoy a much more prominent position, because of the favor he 
1.

靈山紀地德 A numinous ridge documents the earth's virtue; ${ }^{110}$

地險資獄靈 Territorial defenses depend on a great mountain's numinous spirit.

終南表秦觀 Mt. Zhongnan is marked by Qin’s watchtowers;

少室邇王城 The Lesser Chamber presses close to the imperial city.

翠鳳着羽淮海 An azure phoenix soars over the land between Huai River and the sea, ${ }^{111}$

衿帶繞神坷 Lapels and belts surround the divine plain.

北阜何其峻 How steep is the northern peak-

林薄杳葱青 Its trees and plants are a towering green.

received from Emperor Wu’s Crown Prince Xiao Zhangmao

(458-493). He subsequently spent a considerable amount of time in the capital until he was sent away to serve in a provincial post briefly in 494. Xiao Ziming, the Qi crown prince's little brother, was made Prince of Xiyang in 485; it is conceivable that he commissioned Shen Yue, by then a well-established writer in the court circle, to compose a set of poems in the late 480 s or early 490 s. The crown prince Xiao Zhangmao and his younger brother Xiao Ziliang (460-494), the cultured Prince of Jingling , were both devout Buddhists, and Buddhism received a further boost in the Yongming era (483-493) because of their support. One of the five "stanzas" in the set is devoted to the praise of Buddhist monks in Mt. Zhong. Although this does not constitute solid evidence, this "stanza" seems to fit the Yongming scene much better than the early 460 s.

${ }^{110}$ A passage from Guanzi states: "The foremost principle of managing a country lies in the earth's virtue"

. Guanzi, ed. Li Mian ～(Taibei: Shangwu yinshuguan, 1990), 24.462.

${ }^{111}$ This is a traditional expression indicating the south. 
The first couplet creates a palindromic effect: it begins and ends with "ling" 靈; shan Ш and yue 嶽 are synonyms; di (earth) is repeated twice, in di de 地德 and di xian 地險. The palindromic or circular effect adds interest to the somber formality of the statement as well as balances de (virtue) and xian (literally steepness, referring to the difficult terrain that affords an advantage in military actions), respectively implying a ruler's moral capital and military power.

The Qin emperor had erected watchtowers on Mt. Zhongnan to the south of Chang'an; Lesser Chamber was a peak of Mt. Song near the Eastern Han/Western Jin capital Luoyang. ${ }^{112}$ The point is that Qin and Han each had its own famous mountain at their capitals. To associate Mt. Zhongnan with Qin, not with Han, creates a chronological shift in this couplet and a spatial movement from west to east. Both temporal and spatial progress is picked up in the third couplet, which opens with the image of a phoenix soaring over the south-a symbol of the establishment of the southern empire. The phrase "lapels and belts" recalls the Yan Yanzhi couplet from the Onion Hill poem: “The steep defiles had long since left the Han realm; / The collar-and-girdle defenses have moved to the Wu capital” 峳險去漢宇, 衿衛徙吳京. Though he does not explicitly state it like Yan Yanzhi, Shen Yue is moving mountains with the progress of his poem: Mt. Zhong, after an elaborate set up, finally appears in the last couplet, as one towering green. The next three pieces describe the mountain from different aspects, concluding with the last piece depicting the prince's visit. No. 2 continues the "earth" motif:

2.

發地多奇領 Issuing forth from the earth it has many remarkable peaks, 干雲非一狀 Encroaching into the clouds, never of the same appearance.

${ }^{112}$ Wen xuan 22.1059. 
合沓共隱天 Gathering and crowding, they conceal the sky;

參差互相望 Jagged and serrated, they look upon one another.

鬱律構丹巘 Twisted and steep, crimson bluffs are constructed;

崚嶒起青嶂 Tiered and towering, thus built are the blue rocky screens.

勢隨九疑高 Its momentum is as lofty as the Nine Doubts,

氣與三山壯 $\quad$ Its spirit as majestic as the Three Mountains. ${ }^{113}$

3.

即事既多美 Facing the mountain is already full of wonders;

臨眺殊復奇 Looking afar from it is truly marvelous too.

南瞻儲胥觀 To the south one beholds Chuxu Tower;

西望昆明池 Westward one gazes at Kunming Pool. ${ }^{114}$

山中咸可悅 Everything is delightful in the mountain:

賞逐四時移 Our enjoyment changes with the four seasons.

春光發壟首 Spring's rays spread from the high hilltop;

秋風生桂枝 Autumn wind rises from cassia boughs.

\footnotetext{
${ }^{113}$ The Nine Doubts Mountain is in modern Hu'nan; the mountain's nine peaks all look alike, which confuses the visitor, hence "Nine Doubts." It is the burial place of the legendary emperor Shun. The "Three Mountains" refers to the mountain islands of "immortals" in the Eastern Sea: Penglai , Fangzhang , and Yingzhou . Wen xuan 22.1060.

${ }^{114}$ Chuxu Tower and Kunming Pool were both constructed in Chang'an by Emperor Wu of the Han. Ibid.
} 
4.

多值息心侶 We frequently encounter companions of calmed mind, ${ }^{115}$

結架山之足 Who constructed their abodes at the foot of the mountain.

八解鳴澗流 The Eight Liberations resonate with the currents of the ravine;

四禪隱宸曲 The Four Dhyāna heavens are hidden in the bend of the winding cliffs. ${ }^{116}$

窈冥終不見 Profound and subtle, unseen in the end;

蕭條無可欲 Tranquil, relaxed, there is nothing to be desired. ${ }^{117}$

${ }^{115} \mathrm{Xi}$ xin is the translation of the Sanskrit term śramana meaning a Buddhist monk. Ibid.

${ }^{116}$ The eight liberations refer to different stages of mental concentration. The four dhyāna heavens are four heavens that a disciple can attain to through the meditation he observes.

${ }^{117}$ Yaoming, as Li Shan notes, is from Laozi (ch. 21): "How profound! How subtle! In the midst there is an essence" . Li Shan also cites Wang Bi’s (226-249) commentary: "Yaoming describes depth and profundity. It is so deep and profound that one cannot get to see it, and yet the myriad things originate from it” , , , , . For "unseen" and "nothing to be desired," Li Shan again cites Laozi (ch. 3): "Not seeing what one desires makes one's mind unperturbed" $\quad$, . Xiaotiao $\quad$, on the other hand, is a contemporary term that may be best understood in the context of two Shishuo xinyu quotations: one is Zhou Yi's $\quad$ (269-322) statement in no. 22 of the chapter "Grading Excellence" (Pinzao ) that, "In terms of staying relaxed and carefree

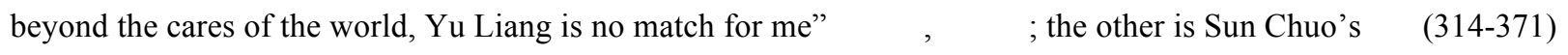
self-description in no. 36 of the same chapter: "From time to time I lodge my feelings in the metaphysical and the transcendent, and intone afar the words of Laozi and Zhuangzi; I live carefree and relaxed, harboring lofty aspirations, and do not concern myself with current affairs - in this I consider this mind of mine as being second to none" $\quad, \quad, \quad, \quad, \quad$. Shishuo xinyu jianshu , , ed. Yu Jiaxi (Shanghai: Shanghai guji chubanshe, 1993), 516, 521. These are Mather's translations, with some revisions. See Richard B. Mather, Shih-shuo Hsin-yü: A New Account of Tales of the World, 2nd ed. (Ann Arbor: Univ. of Michigan Press, 2002), 273, 278. 
所願從之遊 My wish is to roam with them,

寸心於此足 My mind will thereby become content.

5.

君王挺逸趣 The Prince is given to a lofty mood;

羽斾臨崇基 His feathered pennons come to the grand base of the mountain.

白雲隨玉趾 White clouds follow his jade-like footsteps;

青霞雜桂旗 Blue mist mingles with cassia streamers.

淹留訪五藥 Tarrying, he seeks five medicines;

顧步佇三芝 Pacing around, he pauses by the three $z h i$-plants. ${ }^{118}$

於焉仰鑣駕 Thereupon I look up to his carriage with admiration,

歲暮以為期 And hope to make a date for the year's end.

As Richard Mather points out, the second piece is marked by its use of four binomes at the beginning of each line from the third through the sixth, "to create a perception of stupendous height and ruggedness." ${ }^{119}$ These binomes, it needs to be added, are either alliterative or assonant,

${ }^{118}$ Li Shan cites Zheng Xuan's $\quad$ (127-200) commentary to the Zhou li chapter "Jiyi” : : the five drugs refer to plants, trees, insects, minerals, and grains. But wuyao is also a term used in Buddhist scriptures to refer to all kinds of medicines, and its specific contents vary. Likewise, although Li Shan cites Ge Hong to annotate the "three $z h i$ plants," this phrase referring to a group of different fungi is a commonplace term designating the stuff of elixir, and there is no knowing which three fungi Shen Yue had in mind.

${ }^{119}$ Mather, Age of Eternal Brilliance, 1: 6. 
have a jagged sound, and can all be found in Han rhapsodies. ${ }^{120}$ The poem thus turns out to be a condensed verbal imitation of a mountain, a bonsai of a $f u$. The structure of the poem is tight despite its short length: the mention of "clouds" in the second line leads to the rhyming binome heta 合沓 (pronounced hop-dop in reconstructed Middle Chinese pronunciation) in the third line, ${ }^{121}$ which is used to describe clouds in Jia Yi's rhapsody. The third couplet uses verbs, gou 構 and $q i$ 起, that are usually used for architectural construction (Yan Yanzhi's huazao 化造 and shenying 神營 come to mind). The last couplet evokes two sites, one real but associated with a legendary sage king, the other entirely mythical. Neither, it is worth noting, is a northern site.

If the second piece is about the view of the mountain, the third piece describes the view from the mountain, in different directions, and in different seasons. Seasonal changes seem to be part of standard depiction of a scenic site, as in Liu Yigong's and Yan Yanzhi's poems on the Jingyang Tower. The fourth piece shifts focus from the physical view and viewpoint to the spiritual dimension by praising the meditating Buddhist monks at the foot of the mountain. The stress on the invisibility of the Way by the use of such words as yin 隱 and bujian 不見 reflects ironically on the poet's "frequent encounters" with the monks, for the monks' contentment and

\footnotetext{
${ }^{120} \mathrm{Li}$ Shan identifies the last three binomes in various Han rhapsodies; he annotates the first binome, heta, by citing a Xie Lingyun line: "The peaks and ranges are gathering and crowding" ; Wen xuan 22.1060. He may very well be right, since Shen Yue was deeply influenced by Xie Lingyun. But the locus classicus is surely a line describing clouds in Jia Yi's "Rhapsody on Drought Clouds" ～（Quan Han wen 15.208): "They thereupon accumulate and assemble, gathering and crowding” ; cited in Li Shan's commentary to a poem by Xie Tiao in Wen xuan 27.1260.

${ }^{121}$ It is the same as the "reversed" binome tahe (dop-hop).
} 
tranquility become an alluring image that arouses desire in the visitors, with their serene mind ( $x i$ xin 息心) and the poet's heart of yearning (cun xin 寸心) forming a charged contrast.

The last piece turns to the royal prince and his entourage. With terms such as "cassia streamers” (guiqi 桂旗) and “tarrying” (yanliu 淹留), it evokes certain passages from the Verses of Chu (Chuci 楚辭) and Daoist adepts' pursuit of physical immortality. ${ }^{122}$ In some ways, the prince seems to have become one with the mountain: his lofty mood literally "lifts up" (ting 挺) as much as the mountain itself "issues forth" ( $f a$ 發) from the earth; the white clouds follow his yuzhi 玉趾, literally “feet of white jade," and the mist in the mountain, tinted bluish-green by the color of the vegetation, blends with the pennons made of cassia branches. The prince's morphing into the mountain is further borne out in the third couplet that depicts him as lingering among the magical plants. The subtext here is the Western Han Chuci-style poem, "Calling Back the Recluse” (“Zhao yinshi” 招隱士), traditionally attributed to a poet at the court of Liu An 劉安, Prince of Huainan (d. 122 BCE). The famous poem depicts a hauntingly beautiful hillscape and a prince who tarries there and forgets to return, as shown in the excerpt below:

\begin{tabular}{|c|c|}
\hline Dense groves of cassia & in hills' hidden places. \\
\hline Writhing shapes rising, & boughs locked together, \\
\hline where hill vapors loom & with rocks jutting high, \\
\hline where chasms drop deep & and waters raise waves. \\
\hline Packs of apes shriek, & leopards and tigers roar, \\
\hline
\end{tabular}

${ }^{122}$ Wen xuan 22.1061. 


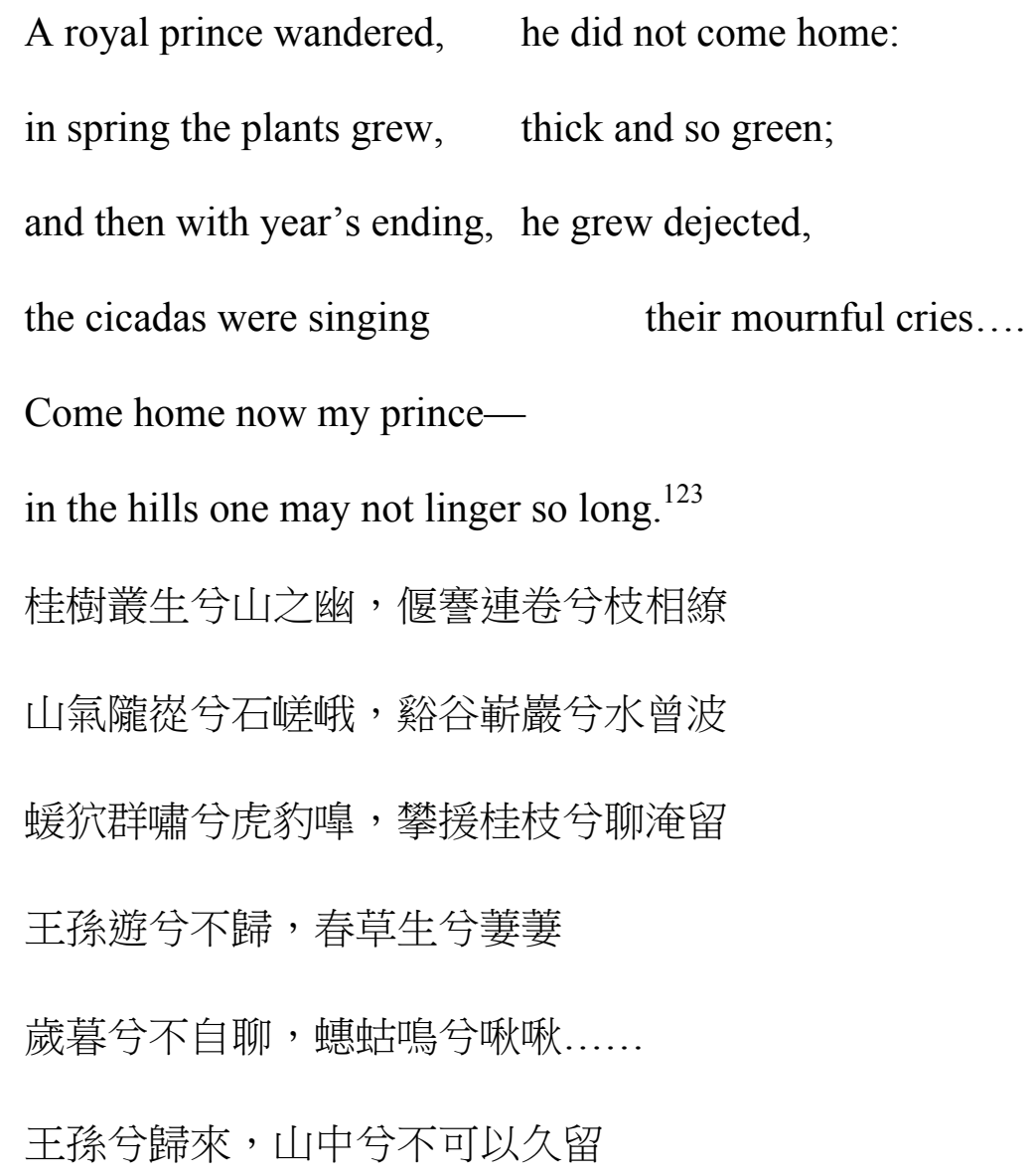

Read in this context, the conclusion of Shen Yue's poetic series turns out to be an artful reworking of the message of "Calling Back the Recluse" - the prince, lured by the beauty of the mountain, is now being urged by the orator to return from his wanderings to his duty at home. Such an ending, instead of the expected apology for the poet's feeble ability, is not inappropriate

${ }^{123}$ Chuci buzhu ， ed. Hong Xingzu (1090-1155) (Taibei: Tiangong shuju, 1989), 12.232-34. Stephen Owen's translation with slight modifications, from Owen, An Anthology of Chinese Literature: Beginnings to 1911 (New York: W.W. Norton, 1996), 211-12. For another English translation, see David Hawkes, The Songs of the South: An Anthology of Ancient Chinese Poems by Qu Yuan and Other Poets (Harmondsworth, Middlesex: Penguin Books, 1985), 244-45. 
if the poet was writing in the Yongming era, an eminent senior courtier and the Crown Prince's favorite Household Provisioner, at the command of the crown prince's little brother.

No matter which Prince of Xiyang_Liu Zishang or Xiao Ziming_-Shen Yue was writing for, "old age" would not happen for the prince, who was killed as a teenager. Both Song and Qi courts were full of bloody coups and intrigues. Underneath the glossy surface of court poetry, there was a violent reality, which perhaps had only made the creation of discursive order even more urgent.

\section{The Problem of "Purple Path": A New Inflection in the Representation of Imperial Power}

In the sixth century, court poetry reached its full flowering under the long, peaceful reign of Emperor Wu of the Liang 梁武帝 (r. 502-549), a poet himself, who had been a close friend of Xie Tiao and Shen Yue and a frequent guest at the residence of the genteel Prince of Jingling of the Qi. The most influential literary figures in the Liang were the refined, erudite, and talented Liang princes, in particular the Crown Prince Xiao Tong 蕭統 (501-531) and, after his premature death, the succeeding Crown Prince Xiao Gang.

During this period representation of kingship and empire was inflected with a harkening back to the early third century. The cultural grace of the Cao Wei 曹魏 rulers held an immense attraction for Xiao Tong, the compiler of Wen xuan, an anthology that, through its strategic selections, cements the image of the Jian'an reign (196-220) as a literary era dominated by the 
Cao family and their followers. ${ }^{124}$ If in Song and Qi times the main frame of reference for the southern courts had been the Three Dynasties of high antiquity and the Qin and Han empires, then during the Liang we begin to see frequent mention of the Cao Wei court as a model. This will be demonstrated in this section by a poem by Liu Xiaochuo 劉孝綽 (481-539), one of the most prominent court poets throughout much of the Liang. ${ }^{125}$ With a close reading of this poem, in particular of a seemingly innocuous literary phrase zimo 紫陌 (“purple path”) in the poem, I will show how the tradition of court poetry, established in the fifth century, continued into the sixth century with a new inflection.

Liu's poem is entitled “On a Spring Day I Follow the Emperor's Carriage to Xinting: Composed at Imperial Command” (“Chunri congjia Xinting yingzhi” 春日從駕新亭應制). ${ }^{126}$ Xinting, to the southwest of Jiankang and overlooking the Yangzi River, was the place where a group of the first-generation northern immigrant elite famously gathered at a picnic and wept

\footnotetext{
${ }^{124}$ For a detailed discussion of the construction of the Jian'an as a literary era, see Xiaofei Tian, "Yanyin yu huiyi: Chongxin sikao Jian'an” $\quad$ : $\quad$, Zhongguo wenxue xuebao $\quad 1$ (2010): 21-34.

${ }^{125}$ Xiaofei Tian, Beacon Fire and Shooting Star: Literary Culture of the Liang (501-557) (Cambridge, Mass.: Harvard Univ. Asia Center, 2007), 127-29.

${ }^{126}$ For another translation of this poem, see Ping Wang, The Age of Courtly Writing: Wen xuan Compiler Xiao Tong (501-531) and His Circle (Leiden: Brill, 2012), 135-36. One interesting thing to note about this poem is that the source texts of almost all its allusions can be found in Wen xuan, in whose compilation Liu Xiaochuo was said to have had a hand. See Kūkai’s ～(774-835) Bunkyō hifuron ～(Beijing: Renmin wenxue chubanshe, 1975), 163. Regardless of whether Liu was a driving force behind the Wen xuan selections or not, he certainly must have exerted an important influence on the young crown prince Xiao Tong, who was twenty years his junior and admired Liu Xiaochuo warmly. See Liang shu （Beijing: Zhonghua shuju, 1973), 33.480.
} 
over the loss of north China. ${ }^{127}$ Throughout the southern dynasties it was a scenic spot for social gatherings and farewell banquets. ${ }^{128}$ Although we do not know in which year Liu Xiaochuo composed this poem, the term yingzhi 應制, like yingzhao 應詔, is used when one is writing at the command of an emperor, who could only be Emperor Wu of the Liang. ${ }^{129}$

The poem begins with the beginning of the day and of the excursion:

旭日輿輪動 The sun rises: carriage wheels start rolling;

${ }^{127}$ Shishuo xinyu 2/92. Xinting was renamed Zhongxing ting (Restoration Station) when Emperor Xiaowu of the Song, who was campaigning against his patricidal brother Liu Shao $\quad$ (d. 453), took the throne there, but the name apparently did not stick. See Song shu 6.110.

${ }^{128}$ To cite a few examples: Fan Yun (451-503), leaving Jiankang for a provincial post, wrote a poem, "Stopping at Xinting on My Way to Lingling Commandary”_ (Lu Qinli, 1550). His friend Xie Tiao saw him off here and wrote a poem, "Saying Farewell to Fan Yun the Magistrate of Lingling" (Lu, 1428). Xu Ling

(507-583), a prominent writer who served in both the Liang and Chen (557-589) courts, composed a poem, "Bidding Farewell at Xinting: Written at the Command of the Crown Prince" ～(Lu, 2532). Xiao Gang also has a poem, “Accompanying His Highness on an Outing to Xinting: Written at the Crown Prince's Command" , which likewise describes a farewell banquet, as its opening couplet states the occasion: "His divine feelings commiserate about the distant journey, / At the fork in the road he lingers in dejection” , (Lu, 1931). Xu Ling's poem uses similar terms: "His divine feelings cherish the traveler going on a distant journey; / Turning his gaze, he looks down the farthest stretch of the clear Zhang” $\quad$,

${ }^{129}$ Liu Xiaochuo had started his official career in the early years of Emperor Wu's Tianjian reign (502-519); Liang shu 33.480. Yingzhao or yingzhi specifically refers to writing at the emperor command; the term for writing at the crown prince's command is yingling , and the term for writing at the command of a prince, yingjiao . 
言追河曲遊 We set out on an outing matching the excursion at the River's bend. ${ }^{130}$

紆餘出紫陌 Winding along, we emerged from the Purple Course;

4 迤邆度青樓 Meandering, we passed the blue mansions.

The first line indicates the time of the day (dawn) and the event (excursion); it also creates a visually evocative effect by the juxtaposition of the image of the rising sun-often figured as driving in a chariot across the sky—and that of rolling carriage-wheels round as the sun. Since this perfectly becomes the common designation of the emperor as the sun, the poet makes a not so subtle hint at the person going on the outing. ${ }^{131}$ Poetic cleverness aside, what most strikes a literary historian is how Liu Xiaochuo explicitly refers to Cao Pi's excursion as a model. While earlier poets had certainly reworked phrases and images from Jian'an writings (Xie Tiao's recycling of Cao Zhi's couplet in "Song of Coming to the Court" is a good example), the difference here is that Liu Xiaochuo evokes Cao Pi's excursion much in the same way as Yan Yanzhi does the "Zhou king's chariot" and "Xia's transports" or as Xie Lingyun does Emperor Yao's Fen River outing.

In the second couplet, zimo 紫陌 (“purple path”) and qinglou 青樓 (“blue mansions”) are such commonplace terms in later tradition that modern readers usually pay no heed to them. Yet, if we historicize their usage, we find much artistic intricacy underneath the seemingly flaccid

130 "Excursion at the River's bend” $\quad$ refers to Cao Pi's description of his springtime outing by the Yellow River in his "Letter to Wu Zhi the Magistrate of Zhaoge” : : "To the north we follow the River's bend" In the same letter Cao Pi reminisces about outings in the old days and uses the phrase, "Carriage wheels moved slowly” . . See Wen xuan 42.1895-96.

${ }^{131}$ Indeed "sun wheels" rilun , a common expression to indicate the sun in medieval writings, is also used to refer to the imperial carriage. 
surface. "Blue mansion" refers to a sumptuous manor whose walls are painted blue with a paint containing azurite. Its locus classicus is Cao Zhi's "Ballad of a Fair Lady" (“Meinü pian” 美女 篇): “Her blue mansion overlooks the great boulevard” 青樓臨大路, which poem is unsurprisingly included in Wen xuan. ${ }^{132}$ In the Qi, however, the people of Jiankang had also referred to Emperor Wu's Xingguang Tower as the "Blue Mansion." Although it was destroyed in $495,{ }^{133}$ the term "blue mansion" must have had a certain contemporary resonance as well as being a textual echo of the Jian'an era.

The "purple path" is the much more intriguing of the two terms. The first known usage of zimo is again found in a Jian'an text, namely, “Rhapsody of Plume Hunt” (“Yulie fu” 羽獵賦) by one of the leading Jian’an writers, Wang Can 王粲 (177-217). The rhapsody, now only fragmentary, depicts a hunt near the city of Ye (in modern Hebei), Cao Cao’s power base: "Having crossed the Zhang River, we lined up in formation on the shore; / By way of zimo we pressed ahead side by side” 濟漳浦而橫陣, 倚紫陌而並征. ${ }^{134}$ Modern annotators all gloss zimo as "path in the suburbs of an imperial capital" or "path in the suburbs."135 However, while we clearly understand why a "blue mansion" is "blue," no attempt seems to have been made to

\footnotetext{
${ }^{132}$ Wen xuan 27.1287.

${ }^{133}$ Nan Qi shu 6.88 .

${ }^{134}$ Quan Hou Han wen 90.959.
}

${ }^{135}$ See Wang Canjizhu ， ed. Wu Yun and Tang Shaozhong (He'nan: Zhongzhou shuhuashe, 1984), 2.50; Jian'an qizi shiwen ji jiaozhu yixi， ed. Han Geping 韓格平 (Changchun: Jilin wenshi chubanshe, 1991); 195; Jian'an qizi ji jiaozhu ， ed. Wu Yun (Tianjin: Tianjin guji chubanshe, 2005), 312; Quan Sanguo fu pingzhu＿＜noBreak>， ed. Gong Kechang ～， Su Guanghuang ～， Su Ruilong ～（Ji'nan: Qilu shushe, 2013), 155. Hanyu dacidian's explanation of the entry is a "path in the suburbs of the capital city" , and cites Wang Can as the earliest example. 
account for $z i$, purple or lavender. To complicate the matter, in extant early medieval belletristic compositions, zimo was rarely, if at all, used between the time of Wang Can and the first half of the sixth century, when we begin to see the term in the writings of Liu Xiaochuo, Xiao Gang, and Xiao Gang's younger brother Xiao Yi 蕭繹 $(508-555){ }^{136}$

What had happened to the phrase zimo during this long interval? If it had been simply an elegant phrase meaning "path in the suburbs," one imagines that it would have been recurrent in literary writings, but it was not. Yet, if we look away from belletristic writings and into contemporary sources of a different nature, we discover that it frequently appears in dynastic histories, where it turns out to be, instead of a "purple path," the name of a river to the northwest of the city of Ye and to the west of the Zhang River. Shi Hu 石虎 (295-349), the Xiongnu ruler of the Latter Zhao, built a pontoon bridge known as Zimo Bridge 紫陌橋 over the river and also constructed a Zimo Palace 紫陌宮 next to it. ${ }^{137}$ Both the river's name and the bridge remained in use in the sixth century, attested by many references made in the History of the Northern Qi (Bei Qi shu 北齊書) compiled by Li Baiyao 李百藥 (565-648), and by a number of tomb inscriptions from the Eastern Wei and Northern Qi dynasties (Ye was the capital of the Northern Qi). ${ }^{138}$

\footnotetext{
${ }^{136}$ For Xiao Gang's and Xiao Yi’s use of the term in prose and poetry, see Quan Liang wen , 14.3031, 18.3056; $\mathrm{Lu}, 1937$

${ }^{137}$ Taiping yulan 73.472, 354.1756, citing Lu Hui's $\quad$ fourth-century Ye zhong ji . The pontoon bridge was built in the eleventh year of the Jianwu era (345). See Shuijing zhu jiaoshi , ed. Chen Qiaoyi (Hangzhou: Hangzhou daxuechubanshe, 1999), 10.179.

${ }^{138}$ Bei Qi shu (Beijing: Zhonghua shuju, 1972), 1.8, 2.24, 8.111, 10.136. Also see Han Wei Nanbeichao muzhi huibian , comp. Zhao Chao (Tianjin: Tianjin guji chubanshe, 1992), 366, 435. A Northern Qi general Qifu Baoda’s $\quad(515-570)$ tomb inscription states that he was "interred on the north shore of Zimo, seven leagues to the northwest of the city of Ye" $\quad$ (Han Wei nanbeichao muzhi huibian, 450). A
} 
Southern Dynasties writers clearly understood Zimo as the name of a river, even as they made use of the color "purple" embedded in the name in creating clever parallel couplets. For instance, Xu Ling's letter to a Yin Yishang 尹義尚 of Ye states: “Baigou's [White Canal] waves are swelling, its spring currents having turned limpid; / Zimo [Purple Course] appears hazy, as the lithe willows [on its banks] grow increasingly dense” 白溝浼浼, 春流已清; 紫陌依依, 長楊稍 合. ${ }^{139}$ Baigou was the name of a Han canal, into which Cao Cao had channeled Qi River in 204 and then again Zhang River in 213. ${ }^{140}$ The juxtaposition of Baigou and Zimo highlights their common nature as place-names.

Liu Xiaochuo is, as far as we know, the first poet after Wang Can who uses Zimo in a poetic text, exploiting its color connotation by pairing it off with qinglou; the Xiao princes followed suit. After that Zimo entered the literary repertoire, and its use became widespread in belletristic writings. ${ }^{141}$ As the city of Ye was effaced in 580 and the local name fell into oblivion,

young prince of the Northern Qi, Gao Senghu

River to the west of the city of Ye"

${ }^{139}$ Quan Chen wen $\quad 10.3454$.

${ }^{140}$ Sanguo zhi (Beijing: Zhonghua shuju, 1959), 1.25, 1.42.

${ }^{141}$ Today the most famous poem that contains the phrase may be the Tang poet Liu Yuxi's "In the Tenth Year of the Yuanhe Reign [815] I Received Summons to Come to the Capital from Langzhou and Playfully Presented This to the Various Gentlemen Viewing Flowers" purple path red dust is blown on one's face: / Everybody says he's just returned from viewing flowers" . Liu Yuxi ji jianzheng , ed. Qu Tuiyuan (Shanghai: Shanghai guji chubanshe, 1989), 24.702. The source for Liu's line is a couplet from the yuefu poem "Chang'an Road" by the famous southern court poet Jiang Zong (519-594): "Hurly-burly, on the Purple Course, / Profuse and dim, red dust flies" ; Lu, 2569.
(568-573), was "interred seven leagues to the north of the Zimo . (p. 464 .

(772-842) quatrain, : "Over the 
later readers continued the textual tradition but seemed to have forgotten the origin of the term. ${ }^{142}$ If the archeology of the phrase Zimo teaches us anything, it is that first, it is always worthwhile to ask simple questions; second, a historicist reading also means reading across material segregated by the division of modern disciplines; and third, the power of literary representation can immortalize physical reality and yet twist it beyond all recognition. The river called Zimo would have gone into complete obscurity if not for literary writings, and yet, once known for what it actually was, in later tradition Zimo simply becomes a mysteriously purple path. Thus Wang Can's line may better be rendered as: “With our back against the Zimo River, we pressed ahead side by side." And Liu Xiaochuo's couplet should be interpreted as: "Emerging from [the bridge over] the Zimo River, the imperial procession meanders past the blue mansions." ${ }^{143}$ The couplet also distinctly recalls the second couplet of Xie Tiao's "Song of Coming to Court" ("Winding off, sashed by green waters, / Far away there rise crimson mansions” 逶迆帶綠水, 迢遞起朱樓), even though Xie depicts approaching Jiankang and Liu is describing a departure from Jiankang. Liu Xiaochuo's couplet likewise uses two binomes (yuyu 紆餘 and yili 迤逦) at the beginning of the lines, but he inverts the colors, thus the "green waters" becoming "Purple Course" while "crimson mansions" becoming "blue mansions." Reworking Xie Tiao's lines by using terms with Cao Wei and contemporary resonance, Liu Xiaochuo achieves a unique effect of a perfect blending of past and present.

\footnotetext{
${ }^{142}$ Ye was burned to the ground and its residents ordered to move forty-five leagues south by the powerful Zhou minister Yang Jian (541-604), who eventually unified China in 589 and was known as Emperor Wen of the Sui .Zizhi tongjian (Beijing: Guji chubanshe, 1956), 174.5426.

${ }^{143}$ It is quite possible that Liu Xiaochuo is referring to the pontoon bridge, named Vermillion Bird Bridge (Zhuque hang ), over the Qinhuai River to the south of Jiankang.
} 
The poem continues as does the progress of the entourage, punctuated by pausing and tarrying, juxtaposing artifice with scenes of nature.

前驅掩蘭徑 The vanguard stops for rest on the flowering path;

後乘歷芳洲 The rear chariots pass by fragrant isles. ${ }^{144}$

春色江中滿 Spring colors fill the River;

8 日華嚴上留 The sun's splendor lingers on the cliffs. ${ }^{145}$

江風傳葆吹 River wind transmits the sound of reed-pipes played by guards of honor;

嚴華映采斿 Colorful banners shining against cliff blossoms.

臨渦起睿作 “Coming upon the Guo waters,” His Highness composes a divine work,

12 馾馬暫停輈 As the four-horse carriage temporarily halts its axles.

“Coming upon the Guo" (“Lin Guo" 臨渦) is the title of a rhapsody composed by Cao Pi. According to the extant preface to the now fragmentary rhapsody, Cao Pi was in Qiao 譙 (in modern Anhui), Cao Cao's hometown, and after paying respects to ancestral tombs, he went on

\footnotetext{
144 "Fragrant isle" evokes: "I pluck pollia on fragrant isles" iㅡ "Lady of the Xiang River" of the "Nine Songs," Chuci buzhu 2.62. Lan used in a parallel position of fang means "sweet-smelling" (from flowers growing alongside), though it is possible to consider the path as lined with magnolias. Lan could also simply mean "lovely," as in Lu Ji's (261-303) Yingjia fu , where the author uses lan in exactly such a purely ornamental way: "Raise a lovely voice to sing beautifully" . Q Quan Jin wen $\quad 96.2012$.

${ }^{145}$ As Ping Wang points out, this couplet reworks two lines in a Xie Tiao poem entitled "Matching a Poem by Capital Minister Xu on Departing from the Xinting Ferry” . The Age of Courtly Writing, 139. Once again, this Xie Tiao poem is anthologized in Wen xuan.
} 
an outing to the Guo River; there "I stopped my horse and composed, with my whip in hand, the 'Rhapsody of Coming upon the Guo.",146 The word guo 渦 also means whirling currents (and as such is pronounced wo in modern Mandarin). Liu thus makes a witty pun by using lin Guo/wo to refer to Cao Pi's rhapsody and the Liang emperor's looking upon the Yangzi currents. The emperor's lingering is echoed in the sun's lingering light on the cliffs covered with blooming flowers, continuing the opening metaphor of the sun's/emperor's carriage.

The line "spring colors fill the River" describes reflections in the river as well as alluding to the spring flood that swells the river. It recalls Xie Lingyun's line in the poem discussed earlier: “From the curtained enclosure, we gaze at the hill's reflection in the water” 張組眺倒景, although Liu's line seems more "modern" because he does not state the action of "gazing" explicitly. Another deliberately artful move made by Liu is the verbal repetition/alternation in lines 7-10: jiang (river) is repeated in 1. 7 and 1. 9; hua yan 華巖 (splendor / cliff) is inverted in line 10 and becomes yan hua 巖華 (cliff blossoms). This creates a circling effect that mimics the pausing and lingering of the imperial entourage in the middle of its linear progress. Finally, lines 7-10 engage several senses, moving from colors, the warmth and gleams of the sunlight, cool river breeze, sound of reed-pipes, back to the colors of the flowers and of the banners, again forming a full circle like the whirling currents. It is a tour-de-force performance of the court poet's craft, a show of talent that no doubt was much appreciated by his discerning imperial patron.

As expected of him, the courtier now takes a theatrically humble bow to his audience upon exit, all the while never forgetting to model his performance on a past age whose cultural glory is in part created by his very adulation of it:

${ }^{146}$ Quan Sanguo wen $\quad 4.1072$. 
侍從榮前阮 Standing in attendance, I receive more honor than did Ruan of old;

雍容慚昔劉 Yet in terms of grace, I am put to shame by the bygone Liu.

空然等彈翰 To no avail do I try to match him in “waving the brush,”

16 非徒媄未遒 Not merely must my Prince lament my “lack of vigor."

The "Ruan of old" and the "bygone Liu" indeed refer to Ruan Yu 阮㻦 (d. 212) and Liu Zhen 劉楨 (d. 217), two of the Jian'an literary masters in the entourage of the Caos. ${ }^{147}$ Wu Zhi, recipient of two famous letters from $\mathrm{Cao} \mathrm{Pi}$, had argued that people like Liu Zhen were good at "standing in attendance gracefully" but would prove useless on a battlefield. Liu Xiaochuo now states that he, though also a Liu, cannot even aspire to match the former Liu's grace, especially his literary elegance; thus, this latter Liu may "raise his brush," but his efforts are all in vain, and his lord would find his poem far worse than merely "lacking in vigor." It must be pointed out that “waving the brush" (tan han 彈翰) is an adroit reversal of "casting aside the brush" (tou han 投翰), a subtle hint at the penultimate line of Liu Zhen's poem “The Lord's Feast” (“Gongyan” 公宴), which, once again, is predictably anthologized in Wen xuan: “Casting aside the brush, I heave a long sigh: / The opulence and splendor are unforgettable” 投翰長歎息, 綺麗不可忘. ${ }^{148}$ While one of the many meanings of the verb tan is indeed "to wave or sway, to move back and

\footnotetext{
${ }^{147}$ The "lack of vigor" is Cao Pi's evaluation of Liu Zhen in another letter addressed to Wu Zhi: "Gonggan [Liu Zhen's courtesy name] has an unrestrained air; it is just that he is not vigorous enough” _ , ; and in lines 13-14 Liu Xiaochuo splits the phrase "standing in attendance gracefully" in Wu Zhi's reply to Cao Pi. See Wen xuan 42.1897, 40.1825 .

${ }^{148}$ Wen xuan 20.945.
} 
forth," it is, judged from extant early medieval writings, highly unusual to apply it to "the brush." ${ }^{149}$ Liu Xiaochuo might very well have made this choice because the sound of tan (dan in Middle Chinese) alliterates with tou (M.C. duw). Just as Yan Yanzhi's contrast of himself with Sima Tan implies a comparison of the Song emperor's outing with Han Wudi's grand ritual journey to Mt. Tai, Liu Xiaochuo's reversal of Liu Zhen's phrasing invites his reader to apply all the "opulence and splendor" depicted in Liu's poem to the present occasion.

Liu Xiaochuo's poem presents a new vision of kingship in the Liang, modeled on an idealized perception of the Jian'an era. The most noteworthy thing about this vision is the explicit articulation of the imperial role in literary and cultural undertakings: the emperor is praised for personally leading his courtiers in literary composition as primus inter pares. As a matter of fact, when Cao Pi composed his rhapsody by the Guo River, he was not even a royal prince yet, and it is only his later enthronement that justifies Liu Xiaochuo's evocation. Yet, Cao Pi was the best model that Liu Xiaochuo could find in a decently distant past.

\section{Coda}

The Southern Dynasties emperors and courtiers were assiduously engaged in the making of a new, southern empire. The making took place on many levels, and here we have focused on

\footnotetext{
${ }^{149}$ Common phrases along this line are nong han (play with the brush), zhen han (raise the brush), ru han (wet the brush). In fact, a search utilizing the Hanji Electronic Database ( ) of Academia Sinica to prove this point yields only two results containing the phrase tan han: one is this poem by Liu Xiaochuo, the other is a stele inscription composed by the northern writer and calligrapher Mu Zirong $\quad$ in 550 (for which, see Quan
} Bei Qiwen 6.3860). 
the literary and architectural representation of kingship and of the capital city Jiankang as the "totemic vestibule" to the southern empire. ${ }^{150}$ As we have seen, the discursive construction and physical construction of imperial power of which Jiankang is a powerful emblem are closely tied to each other. Meaning needs to be articulated in words, and words need external symbols to become brightly manifest. As the introduction to the handsomely illustrated volume The Courts of Europe reminds us:

A court did not serve merely as the home and government headquarters of a ruler. It can also be observed as the nucleus of a ruling class, as a planned monumental environment, as a prime focus of culture. But its basic political function was to serve as a medium of propaganda suggesting power and stability. In an age when Church and State tended to be dominated by physical symbols, a court naturally tried to become a permanent pageant: a construction of grandiose buildings, art treasures, overdressed grandees so brilliant as to dazzle the beholder and to impress even the subjects and the foreign rivals who learned of it at second hand. $^{151}$

Nearly a hundred fifty years elapsed between Emperor Wen of the Song's celebrated Yuanjia reign and the collapse of the Liang in the mid-sixth century. Jiankang became the most populous metropolis in the contemporary world during the Liang and, more important, was

\footnotetext{
${ }^{150}$ Greg Woolf uses this phrase to describe twentieth-century New York in "The City of Letters," in Rome the Cosmopolis, ed. Catharine Edwards and Greg Woolf (Cambridge: Cambridge Univ. Press, 2003, 204.

${ }^{151}$ The Courts of Europe: Politics, Patronage and Royalty: 1400-1800, ed. A. G. Dickens (London: Thames and Hudson, 1977), 7.
} 
transformed from a city into an imperial capital as well as a cultural capital. Yu Xin's deceptively simple quatrain, “Gazing at Wei River” (“Wang Wei shui” 望渭水), was written when he was a permanent exile in the north after the fall of the south: ${ }^{152}$

樹似新亭岸 The trees resemble those on the bank at Xinting;

沙如龍尾灣 The sandy shore is like that of Dragon Tail Inlet.

猶言吟暝浦 I still think that I am chanting at the darkening ford-

應有落帆還 Where a boat with dropped sails should be coming home. ${ }^{153}$

Xinting and Dragon Tail Inlet are, as pointed out before, both southern place-names. Xinting, moreover, is the location of the first gathering in the South, where certain Eastern Jin grandees — émigrés from the north—lamented how Xinting's scenery reminded them of their now lost Luoyang. ${ }^{154}$ For over a century, southern court poets used northern place-names as points of reference for the south, but in this poem Yu Xin turns the tables and instead states that Chang'an reminds him of Jiankang.

Finally, Dragon Tail Inlet deserves a second look because it is such a local place-nameonly the natives or long-term residents of Jiankang would have known about it. A contemporary southern pop song sings of it, pairing it off with Xinting:

\footnotetext{
${ }^{152}$ Lu Qinli, 2406.

${ }^{153}$ This is a reference to the renowned Liang poet He Xun's (d. ca. 518) poem about homesickness; Lu, 1691.

For a more detailed discussion of the poem, see Tian, Beacon Fire and Shooting Star, 397-98.

${ }^{154}$ Shishuo xinyu $2 / 92$.
} 
石頭龍尾彎 Dragon Tail Inlet at Stone Fortress,

新亭送客渚 The isle for seeing guests off at Xinting-

酤酒不取錢 I serve you ale, but I don't take your cash,

郎能飲幾許 How much, loverboy, can you drink after all?

One wonders if $\mathrm{Yu}$ Xin knew this romantic song, and if its melody was haunting his mind when he composed his quatrain. One thing is certain: his poem can only be appreciated with the knowledge and understanding of a long history of the making of the southern empire. 